\title{
Early accumulation of intracellular fibrillar oligomers and late congophilic amyloid angiopathy in mice expressing the Osaka intra-A $\beta$ APP mutation
}

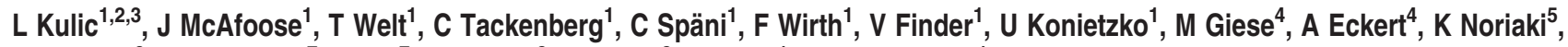

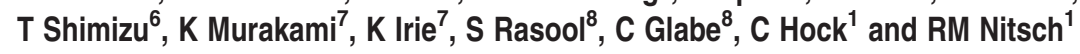

Pathogenic amyloid- $\beta$ peptide precursor (APP) mutations clustered around position 693 of APP-position 22 of the A $\beta$ sequence-are commonly associated with congophilic amyloid angiopathy (CAA) and intracerebral hemorrhages. In contrast, the Osaka (E693 $\Delta$ ) intra-A $\beta$ APP mutation shows a recessive pattern of inheritance that leads to AD-like dementia despite low brain amyloid on in vivo positron emission tomography imaging. Here, we investigated the effects of the Osaka APP mutation on $A \beta$ accumulation and deposition in vivo using a newly generated APP transgenic mouse model (E22 $\triangle A \beta)$ expressing the Osaka mutation together with the Swedish (K670N/M671L) double mutation. E22 $\triangle A \beta$ mice exhibited reduced $\alpha$-processing of APP and early accumulation of intraneuronal fibrillar $A \beta$ oligomers associated with cognitive deficits. In line with our in vitro findings that recombinant E22 $\Delta$-mutated A $\beta$ peptides form amyloid fibrils, aged E22 $\triangle A \beta$ mice showed extracellular CAA deposits in leptomeningeal cerebellar and cortical vessels. In vitro results from thioflavin $T$ aggregation assays with recombinant $A \beta$ peptides revealed a yet unknown antiamyloidogenic property of the E693 $\Delta$ mutation in the heterozygous state and an inhibitory

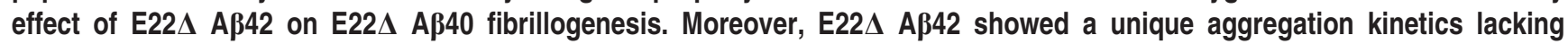
exponential fibril growth and poor seeding effects on wild-type $A \beta$ aggregation. These results provide a possible explanation for the recessive trait of inheritance of the Osaka APP mutation and the apparent lack of amyloid deposition in E693 $\Delta$ mutation carriers.

Translational Psychiatry (2012) 2, e183; doi:10.1038/tp.2012.109; published online 13 November 2012

\section{Introduction}

Extracellular deposition of fibrillar amyloid- $\beta$ (A $\beta)$ peptide as amyloid plaques and congophilic amyloid angiopathy (CAA) is considered a cardinal neuropathological feature of Alzheimer's disease (AD). ${ }^{1,2}$ According to the amyloid cascade hypothesis, soluble and fibrillar $A \beta$ species have a central role in the pathogenesis of $A D$ and start to accumulate within the brain years before cognitive decline and dementia symptoms are observed. ${ }^{3}$ Evidence supporting the amyloid cascade hypothesis comes from several sources including genetic studies of familial AD cases carrying mutations in the amyloid$\beta$ peptide precursor $(A P P)$ gene and the presenilin genes. ${ }^{3,4}$ Pathogenic mutations in the APP gene have been shown to influence the metabolism of the $A \beta$ peptide in various ways. The Swedish double mutation (K670N/M671L), located upstream of the $A \beta N$ terminus adjacent to the $\beta$-cleavage site, results in an increased production of both $A \beta 40$ and $A \beta 42$ species, ${ }^{5-7}$ whereas mutations located at the $\gamma$-cleavage site of APP cause an increase of the $A \beta 42 / A \beta 40$ ratio and, as a consequence of this, result in increased $A \beta$ aggregation and deposition (for a review see Goate $^{8}$ ). The recently discovered
E693 $\Delta$ Osaka mutation in a Japanese pedigree ${ }^{9}$ is one of the six so-called intra-A $\beta$ mutations clustered around the hydrophobic core of the $A \beta$ sequence. Position 693 seems to be a critical site involved in pathogenic aggregate formation since mutations at or $( \pm 1)$ around this site, including the Dutch $(\mathrm{E} 693 \mathrm{Q}),{ }^{10}$ Flemish (E692G), ${ }^{11}$ Italian (E693K), ${ }^{12}$ lowa $(\mathrm{D} 694 \mathrm{~N})^{13}$ and Arctic (E693G) ${ }^{14}$ mutations, have been reported to result in an increase in total $A \beta$ production ${ }^{15}$ and-with the exception of the Flemish mutation-enhance $A \beta$ aggregation and toxicity. ${ }^{16,17}$ Interestingly, all currently known intra-A $\beta$ APP mutations-with the exception of E693 4 - have previously been shown to be vasculotropic and are characterized neuropathologically by prominent vascular amyloid deposition. ${ }^{18}$

Although neuropathological data have not been reported to date, homozygous carriers of the recessive Osaka APP mutation are believed to develop an AD-like clinical phenotype in the absence of relevant extracellular amyloid deposition as revealed by a very low signal on amyloid positron emission tomography imaging. ${ }^{9}$ In vitro experiments demonstrated enhanced oligomerization but no fibrillization of synthetic

\footnotetext{
${ }^{1}$ Division of Psychiatry Research, University of Zurich, Zurich, Switzerland; ${ }^{2}$ Department of Neurology, University Hospital Zurich, University of Zurich, Zurich, Switzerland; ${ }^{3}$ Zurich Center for Integrative Human Physiology (ZIHP), University of Zurich, Zurich, Switzerland; ${ }^{4}$ Neurobiology Research Laboratory, Psychiatric University Clinics, University of Basel, Basel, Switzerland; ${ }^{5}$ mmuno-Biological Laboratories, Fujioka-shi, Gunma, Japan; ${ }^{6}$ Department of Advanced Aging Medicine, Chiba University Graduate School of Medicine, Chiba, Japan; ${ }^{7}$ Division of Food Science and Biotechnology, Graduate School of Agriculture, Kyoto University, Kyoto, Japan and ${ }^{8}$ Department of Molecular Biology and Biochemistry, University of California,, Irvine CA, USA

Correspondence: Dr L Kulic, Division of Psychiatry Research, University of Zurich, August-Forel-Strasse 1, Zurich 8008, Switzerland.

E-mail: luka.kulic@bli.uzh.ch
}

Keywords: Alzheimer's disease; APP; congophilic amyloid angiopathy; intraneuronal A $\beta$; Osaka mutation

Received 19 June 2012; revised 4 September 2012; accepted 4 September 2012 
$E 22 \Delta A \beta 40$ and $E 22 \Delta A \beta 42$ preparations, suggesting that $A D$ like symptoms may be caused by the presence of synaptotoxic $A \beta$ oligomers, rather than fibrillar $A \beta$, in the affected patients. ${ }^{9}$ Consistent with these findings, synthetic E22 $\Delta$ A 342 potently inhibited hippocampal long-term potentiation $^{9,19}$ and induced synapse loss in mouse hippocampal slices. ${ }^{20}$ Further cell culture experiments and results from the recently reported $E 693 \Delta$ transgenic mouse model revealed enhanced accumulation of intraneuronal $A \beta$ oligomers as a prominent feature of the Osaka APP mutation. ${ }^{21-23}$ E693 $\Delta$ transgenic mice start to accumulate intraneuronal $A \beta$ aggregates at an age of 8 months and are completely devoid of extracellular amyloid deposits up to an age of 24 months. ${ }^{22}$ The apparent lack of extracellular amyloid deposition in these mice has been suggested to be in line with the initial in vitro findings with synthetic $A \beta$ preparations that $E 22 \Delta$-mutated $A \beta$ peptides do not form amyloid fibrils. ${ }^{9}$

However, follow-up studies with recombinant $A \beta$ preparations revealed that both $E 22 \Delta A \beta 40$ and E22 $\Delta A \beta 42$ readily formed amyloid fibrils in vitro. ${ }^{24}$ Based on these findings, we hypothesized that E22 $\Delta$-mutated $A \beta$ may, in principle, also form amyloid fibrils in vivo and generated a novel APP transgenic mouse line $(E 22 \Delta A \beta)$ to investigate the effects of the E693 $\Delta$ mutation on amyloid accumulation and deposition in vivo. In line with our recent in vitro findings, ${ }^{24}$ aged E22 $\Delta \mathrm{A} \beta$ mice were characterized by late extracellular amyloid deposition in the leptomeningeal vasculature at 24 months of age, which was preceded by an early accumulation of intracellular oligomeric $A \beta$ species already at an age of 3 months. The results of this study provide strong evidence that E22 $\Delta$ mutated $A \beta$ species are fibrillogenic and can deposit extracellularly in vivo as CAA, thus placing the E693ム Osaka mutation on the list of other vasculotropic intra-A $\beta$ APP mutations.

\section{Materials and methods}

Animals. The newly generated $E 22 \Delta A \beta$ mice express the human APP695 isoform containing the Swedish (K670N+ $\mathrm{M} 671 \mathrm{~L})$ and Osaka (E693 $\Delta$ ) mutations. The mutations were generated by site-directed mutagenesis of pGEM-9zf(-)huAPP695. The cDNA was inserted into pMoPrP-Xho, ${ }^{25}$ and the construct was sequenced. After removal of the vector sequence, the linear construct was injected into the pronuclei of fertilized zygotes of B6D2F1 mice. Founders were screened for transgene expression by tail polymerase chain reaction and western blot analysis, and the line used in this project was expanded on the hybrid background of C57BI/6 and DBA/2 (B6D2). For all behavioral, biochemical and histological analyses, offspring from the B6D2 generation backcrossed once with pure $\mathrm{C} 57 \mathrm{BI} / 6$ was used. Mice were kept on a $12 \mathrm{~h}$ light/dark cycle at $22^{\circ} \mathrm{C}$. Food pellets and water were available ad libitum.

For histological and western blot analyses, mice at different ages were anesthetized and transcardially perfused with icecold phosphate-buffered saline. One hemibrain was dissected into cortex and hippocampus, frozen in liquid nitrogen and stored at $-80^{\circ} \mathrm{C}$. The other hemibrain was postfixed in $4 \%$ $\left(w^{-1}\right)$ paraformaldehyde in phosphate-buffered saline overnight at $4{ }^{\circ} \mathrm{C}$ and embedded in paraffin.
All animal experiments were performed in compliance with Swiss national guidelines and were approved by the veterinarian authorities of the Canton of Zurich.

Protein extracts and western blotting. Brain tissues were homogenized with a glass teflon homogenizer in a sixfold wet weight amount of buffer A containing $100 \mathrm{~mm}$ Tris- $\mathrm{HCl}$, $150 \mathrm{~mm} \mathrm{NaCl}$, Complete Protease Inhibitor Cocktail (Roche Diagnostics, Rotkreuz, Switzerland) and Phosphatase Inhibitor Cocktails $1+2$ (Sigma-Aldrich, Buchs, Switzerland). After centrifugation at $100000 \mathrm{~g}$ for $1 \mathrm{~h}$, supernatants were collected (= Tris fraction) and pellets were rehomogenized in buffer A containing 1\% Triton X-100. Centrifugation at $100000 \mathrm{~g}$ was repeated and supernatants were again collected (= Triton fraction). The remaining pellets were rehomogenized in buffer A containing $2 \%$ sodium dodecyl sulfate (SDS). After an additional centrifugation step and collection of the supernatants (=SDS fraction), the resulting pellets were eventually dissolved in $70 \%$ formic acid (FA), sonicated for $30 \mathrm{~s}$ at $30 \%$ power, ultracentrifuged, supernatants extracted, lyophilized and reconstituted in buffer A containing $2 \%$ SDS for further analysis. Total protein concentrations were measured with the DC protein assay (Bio-Rad Labs, Gessier, Switzerland). Extracts were separated by SDSpolyacrylamide gel electrophoresis, blotted onto nitrocellulose, boiled for $5 \mathrm{~min}$ in phosphate-buffered saline and blocked in Tris-buffered saline containing $5 \%$ milk for $1 \mathrm{~h}$ at room temperature. Primary antibodies were incubated overnight at $4{ }^{\circ} \mathrm{C}$ (6E10 1:500; anti-C-terminal APP (Sigma, Buchs, Switzerland); 1:2000) and visualized by peroxidaseconjugated antibodies and ECL reactions (Amersham Biosciences, Otelfingen, Switzerland). Monoclonal anti- $\beta$-actin antibody (1:2000; Abcam, Cambridge, UK) was used as internal loading control and for normalization of densitometric analyses of the immunoreactive bands. Quantification of the immunoreactive bands was carried out by densitometry of the scanned films under conditions of non-saturated signal using the Image J software (rsb.info.nih.gov/ij/).

MSD analysis. $A \beta$ fragments were measured in the abovementioned brain homogenate fractions and plasma was measured using a MesoScale Discovery (MSD) 3plex multiSPOT $A \beta$ human kit (Gaithersburg, MD, USA) for $A \beta_{38}, A \beta_{40}$ and $A \beta_{42}$, in accordance with the manufacturer's instructions. Human SAPP $\alpha$ levels were determined using an MSD 2plex kit (Gaithersburg, MD, USA), and human Swedish sAPP $\beta$ levels were determined using an MSD 1plex kit (Gaithersburg, $M D, U S A)$, in accordance with the manufacturer's instructions. All reagents were provided with the kits containing a 96-well plate with two carbon electrodes precoated with analyte-specific capture antibodies. After $1 \mathrm{~h}$ of blocking with bovine serum albumin, plates were washed with Tris wash buffer and samples and standards added to the wells. Plates were sealed and incubated for $1 \mathrm{~h}$ on an orbital shaker (750 r.p.m.) at room temperature, followed by additional washing steps and incubation with the detection antibody for $1 \mathrm{~h}$. For A $\beta$ 3plex assay (Gaithersburg, MD, USA), standards and samples were added at the same time as the detection antibody, and plates were incubated for $2 \mathrm{~h}$. At the end of the incubation period, plates were washed again and measured 
on an MSD SECTOR Imager 6000 plate reader (Gaithersburg, $M D$, USA) after the addition of the MSD Read Buffer T (Gaithersburg, MD, USA). Raw data were measured as electrochemiluminescence (light) signal detected by photodetectors. The MSD DISCOVERY WORKBENCH software (Version 3.0.17) (Gaithersburg, MD, USA) with Data Analysis Toolbox was used to calculate sample concentrations by comparing them against a standard curve.

Histological analysis. Histological stainings were carried out on $5 \mu \mathrm{m}$ paraffin brain sections by using standard published procedures. For the immunohistochemical detection of intraneuronal $A \beta$ deposits, sections were boiled in $10 \mathrm{~mm}$ sodium citrate buffer ( $\mathrm{pH} 6.0)$, followed by antigen retrieval with $95 \% \mathrm{FA}$ for $5 \mathrm{~min}$. The following antibodies were used for immunohistochemistry: 6E10 (1:500 dilution; Signet, Dedham, MA, USA) and $\beta$-amyloid antibody (1:200 dilution; Cell Signaling, Danvers, MA, USA) were used for the detection of pan-A $\beta$. Anti- $\beta$-amyloid protein (1-40) antibody (1:100; Sigma) and BA27 (Amyloid $\beta$-Protein Immunohistostain Kit; Wako, Wako Chemicals $\mathrm{GmbH}$, Neuss, Germany) were used to specifically detect $A \beta 40$. $\beta$-Amyloid 42 Polyclonal Antibody (1:100; Signet) and BC05 (Amyloid $\beta$-Protein Immunohistostain Kit; Wako) were used to specifically detect $A \beta 42$. Polyclonal antibodies $A 11$ and $O C$ (provided by $C$ Glabe, both 1:100) were used for the detection of prefibrillar and fibrillar $A \beta$ oligomers, respectively. 11A1 (1:100; IBL Japan, Gunma, Japan) was used to detect $A \beta$ with a conformational turn epitope between positions 22 and 23 of the $A \beta$ sequence. ${ }^{26}$ Anti-Amyloid Precursor Protein, C-Terminal antibody (1:200; Sigma) was used for the detection of full-length APP and APP C-terminal fragments. Secondary antibodies were obtained from Vector Laboratories, Burlingame, CA, USA (Vectastain ABC kits PK-6101 and PK-6102) for peroxidase diaminobenzidine stainings, and from Jackson Immunoresearch Laboratories (West Grove, PA, USA) for immunofluorescence.

Thioflavin $S$ staining and Congo red stainings were performed according to standard protocols as described previously. ${ }^{27}$

Recombinant $\mathbf{A} \boldsymbol{\beta}$ production. Production of recombinant $A \beta$ peptides (wild-type $A \beta 40$ and $A \beta 42, E 22 \Delta A \beta 40$ and $A \beta 42$, and E22G $A \beta 40$ and $A \beta 42$ ) was performed as described previously. ${ }^{28}$ In brief, recombinant $A \beta$ peptides were expressed under the control of the T7 promoter/lac operator in Escherichia coli BL21 (DE3) as fusion proteins to the peptide sequence (NANP) ${ }_{19}$ with an N-terminal hexahistidine tag. Mutagenesis at codon 22 in both $A \beta 1-40$ and A $\beta 1-42$ was performed with the QuikChange site-directed mutagenesis kit (Stratagene, Basel, Switzerland). The correct genetic sequences of the constructs were verified by DNA sequencing. Cleavage of the fusion proteins $(100 \mu \mathrm{M})$ with $7.5 \mu \mathrm{m}$ tobacco etch virus protease was performed in $10 \mathrm{~mm}$ Tris- $\mathrm{HCl}(\mathrm{pH} 8.0), 0.5 \mathrm{~mm}$ ethylenediaminetetraacetic acid and $1 \mathrm{~mm}$ dithiothreitol for $1 \mathrm{~h}$ at room temperature, followed by incubation at $4{ }^{\circ} \mathrm{C}$ overnight. The cleaved $A \beta$ peptides precipitated during the cleavage reactions and were pelleted by centrifugation $\left(4500 \mathrm{~g}, 20 \mathrm{~min}, 4^{\circ} \mathrm{C}\right)$, dissolved in $6 \mathrm{M}$ guanidinium chloride- $\mathrm{HCl}(\mathrm{pH} 2.0)$ and purified via reversed-phase high-performance liquid chromatography. Peptides were eluted with CAN, aliquoted in Protein LoBind Eppendorf tubes (Vaudaux-Eppendorf), lyophilized and stored at $-80^{\circ} \mathrm{C}$. The high purity and identity of the peptides were verified by matrix-assisted laser desorption/ionization timeof-flight mass spectrometry using sinapinic acid as matrix.

Thioflavin $\mathbf{T}$ aggregation assays. Preparation of $A \beta$ solutions and thioflavin $\mathrm{T}$ aggregation assays were performed as described earlier. ${ }^{24,28}$ In brief, $A \beta$ variants were dissolved in $10 \mathrm{~mm} \mathrm{NaOH}$ to concentrations of $100-150 \mu \mathrm{m}$. $A \beta$ concentrations were determined via the absorbance of $A \beta$ at $280 \mathrm{~nm}$ in $10 \mathrm{~mm} \mathrm{NaOH}$ (extinction coefficient at $280 \mathrm{~nm}$ and $\mathrm{pH} 12$ corresponding to a single tyrosine residue: $\left.1730 \mathrm{M}^{-1} \mathrm{~cm}^{-1}\right)$. Stock solutions were kept on ice and were used for aggregation experiments within $6 \mathrm{~h}$. Aggregation reactions were performed at $37^{\circ} \mathrm{C}$ with 2.5 or $5 \mu \mathrm{m} \mathrm{A} \beta$ (final concentration) in $10 \mathrm{~mm} \mathrm{H}_{3} \mathrm{PO}_{4}-\mathrm{NaOH}(\mathrm{pH} 7.4), 100 \mathrm{~mm} \mathrm{NaCl}$ and $35 \mu \mathrm{m}$ thioflavin $\mathrm{T}$ in a volume of $1000 \mu \mathrm{l}$ in stirred quartz fluorescence cuvettes $(1-0.4 \mathrm{~cm})$. The thioflavin $T$ concentration was determined via its extinction coefficient of $36000 \mathrm{M}^{-1} \mathrm{~cm}^{-1}$ at $412 \mathrm{~nm}$. Aggregation reactions were started by a dilution of the $A \beta$ stock solution in $10 \mathrm{~mm} \mathrm{NaOH}$ (prepared and ultracentrifuged immediately before use) with an aggregation buffer mix, resulting in $\mathrm{pH} 7.4$, and the final concentrations indicated above. Thioflavin $\mathrm{T}$ fluorescence emission at $482 \mathrm{~nm}$ (excitation at $440 \mathrm{~nm}$; excitation and emission slit at $1.6 \mathrm{~nm}$ ) was monitored on a Quantamaster (QM-7/2003) fluorescence spectrometer (Photon Technology International, Birmingham, NJ, USA).

Cognitive-behavioral testing. A battery of well-validated and carefully controlled tests was used to behaviorally assess mice for motoric and cognitive performance. ${ }^{29}$ At the time of testing, mice were weighed and examined for general health measures to ensure that the mice were physically able to conduct the cognitive-behavioral test. ${ }^{29}$

Locomotor activity in the open field test. According to published procedures, mice were placed in the center of a brightly-lit white Plexiglas box $\left(50 \times 50 \mathrm{~cm}^{2}\right)$, and their movements (distance traveled and average speed) were tracked using ANY-maze video tracking software (Stoelting, Wood Dale, IL, USA) for $5 \mathrm{~min}$.

$Y$-maze. Spatial working memory was assessed in mice using the Y-maze (Y-shaped plastic maze, with $40 \times 20 \times 10$ $\mathrm{cm}^{3}$ arm sizes). During a 5-min trial, the sequence of arm entries was recorded using the ANY-maze Video Tracking System (Stoelting). The percentage alternation was calculated as the ratio of actual to possible alternations (defined as the total number of arm entries -2$) \times 100 \%$.

Barnes maze. The Barnes maze was used to assess hippocampus-dependent spatial learning and memory. ${ }^{30}$ The Barnes maze consists of a gray, acrylic, circular disk $91 \mathrm{~cm}$ in diameter with 20 equally spaced holes $(5 \mathrm{~cm}$ in diameter) located $1.5 \mathrm{~cm}$ from the edge, and elevated $90 \mathrm{~cm}$ above the floor. The platform was illuminated by a $100 \mathrm{~W}$ electric bulb located $110 \mathrm{~cm}$ above the center of the maze 
(150 Ix), thus providing motivation for the animals to avoid the open surface and escape into a small dark recessed chamber (escape box) located under the platform. The inclusion of false boxes that look the same as the target escape box, but are too small to be entered, were used to remove visual cues that might allow the mouse to discriminate the location of the escape hole from the other holes. A cylindrical plastic start chamber $(10.5 \mathrm{~cm}$ diameter, $9.5 \mathrm{~cm}$ height) was used to hold mice in the middle of the maze at the start of each trial. A web camera (Logitech, Zurich, Switzerland) was placed $1.2 \mathrm{~m}$ above the center of the maze to record trials using the ANY-maze Video Tracking System (Stoelting). Distinct spatial cues placed in a constant location around the maze served as a reference point to learn the position of the escape hole.

Mice completed 4 days of acquisition training with four trials per day with an inter-trial interval of 10-15 min. For each trial, mice were placed in the start chamber in the middle of the maze, and after $10 \mathrm{~s}$, the start chamber was raised to start the trial and the mouse was allowed to explore the maze for $3 \mathrm{~min}$. During these $3 \mathrm{~min}$, the latency to enter the escape box, distance traveled, speed, time spent immobile and search strategy used was measured, among other parameters. The trial ended when the mouse successfully entered the escape box or after the $3 \mathrm{~min}$ had elapsed. If a mouse did not successfully enter the escape box during the $3 \mathrm{~min}$, it was placed back at the start position and gently guided to the escape hole, where the mouse remained in the escape box for $1 \mathrm{~min}$. At the end of each trial, mice were returned to their holding cage until the next trial. To reduce intramaze odor cues, the maze surface and escape box were cleaned with $70 \%$ ethanol after each trial. Search strategies were determined by examining individual track plots for each mouse per day and classifying their ability to find the escape location as either: (1) random search strategy-search patterns that cross through the center of the maze in a completely random manner; (2) serial search strategy-in which mice search every hole or every other hole in a clockwise or counterclockwise systematic manner; or (3) spatial search strategyin which the mice were able to locate the escape box directly plus or minus two adjacent holes within the target quadrant only.

Statistical analysis. Data analysis was performed using the Statistica 10.0 (StatSoft Inc, Tulsa, OK, USA) and SPSS 19.0 (16M, Schweiz, Zurich, Switzerland) statistical software. Tests for normal distribution were performed before statistical testing, according to the results of the Shapiro-Wilk and the Kolmogorov-Smirnov test for normality, either Student's $t$-test or Mann-Whitney $U$-test for two sample groups or analysis of variance was performed (followed by post-hoc Fischer's least significant difference analysis). A $P$-value $<0.05$ was considered statistically significant. Error bars are s.e.m.

\section{Results}

Transgene expression and APP processing. The newly generated E22 $\triangle \mathrm{A} \beta$ mice overexpress the human APP695 isoform containing the Swedish (K670N + M671L) and Osaka (E693 $\Delta)$ mutations. The Swedish double mutation was introduced to increase the amount of total secreted $A \beta$ without affecting the $A \beta 42 / A \beta 40$ ratio. Several transgenic founder lines were analyzed for brain expression of the fulllength human APP transgene, and a line expressing transgene levels comparable to our APP transgenic $\operatorname{arcA} \beta$ mouse model (expressing APP with the Swedish and Arctic (E693G) mutations) and the widely established Tg2576 AD mouse model (expressing APP with the Swedish mutation alone) was chosen for further analysis (Figure 1a). Western blot analysis of SDS extracts revealed similar full-length APP and $\beta$-stub (C99) levels in the $E 22 \Delta A \beta, \operatorname{arcA} \beta$ and Tg2576 mice (Figure 1a). $\alpha$-Stub (C83) levels, however, were significantly reduced in both $E 22 \Delta \mathrm{A} \beta$ and $\operatorname{arcA} \beta$ mice as compared with Tg2576 mice (Figure 1a). MSD assay analysis of soluble APP levels from SDS brain extracts revealed a two- to threefold reduction in SAPP $\alpha$ levels in the $\mathrm{E} 22 \Delta \mathrm{A} \beta$ and $\operatorname{arcA} \beta$ mice. In contrast, sAPP $\beta$ levels were comparable to the Tg2576 mice (Figure 1b). These findings indicate that both intra-A $\beta$ APP mutations at position 22 of the $A \beta$ sequence specifically interfere with the $\alpha$-secretase processing of APP in vivo.

Age-dependent changes in $\mathbf{A} \boldsymbol{\beta}$ levels. As a next step, we used MSD technology to determine $A \beta$ levels in four sequentially extracted protein fractions from the cortical brain tissue (Figure 2). In agreement with previous findings, 27,31,32 Tg2576 and $\operatorname{arcA} \beta$ mice showed an age-dependent exponential accumulation of $A \beta$ in detergent-insoluble (FAsoluble) protein fractions (Figure $2 \mathrm{e}-\mathrm{k}$ ) that accompanied the occurrence of parenchymal amyloid deposits in these mouse models (data not shown). $A \beta$ accumulation occurred earlier and was more pronounced in the $\operatorname{arc} A \beta$ mice as compared with age-matched Tg2576 mice (Figure 2e-k), as previously reported in immunohistological findings. ${ }^{27,31}$ In contrast, most of the $A \beta$ in the E22 $\Delta A \beta$ mice accumulated in the detergent-soluble (SDS) protein fraction up to the age of 15 months (Figure 2a-c). MSD analysis of Tris buffer and mild detergent (Triton $\mathrm{X}-100$ ) extracts in the $\mathrm{E} 22 \Delta \mathrm{A} \beta$ mice revealed only very low $A \beta$ levels as compared with the Tg2576 mice (Figure 2a-c). In addition, E22 $\Delta A \beta$ mice (similar to the $\operatorname{arcA} \beta$ mice) showed four- to fivefold lower plasma A $\beta$ levels than the Tg2576 mice (Supplementary Figure 1). These results indicate that the lack of accumulation of detergent-insoluble $A \beta$ in the $E 22 \Delta A \beta$ mice up to the age of 15 months was not accompanied by a relative increase in soluble brain or peripheral (plasma) $A \beta$ levels. Western blot analysis of the four protein fractions at 15 months further confirmed the MSD findings (Supplementary Figure 2). At 24 months of age, however, a significant increase in detergent-insoluble (FA-soluble) A $\beta$ was observed in the E22 $\Delta A \beta$ mice (Figure $2 d$ ). This change in $A \beta$ solubility provided the first biochemical evidence for a substantial accumulation of fibrillar amyloid deposits in aged $\mathrm{E} 22 \Delta \mathrm{A} \beta$ mice, even though FA-soluble $\mathrm{A} \beta$ levels remained relatively low in comparison to amyloid depositing Tg2576 and $\operatorname{arcA} \beta$ mice at 15 months (Figure $2 b$ and $c$ ).

Late CAA in the absence of amyloid plaque deposition. Immunostainings of paraffin-embedded brain sections from aged $E 22 \Delta A \beta$ mice with $A \beta$-specific antibodies showed no 
a
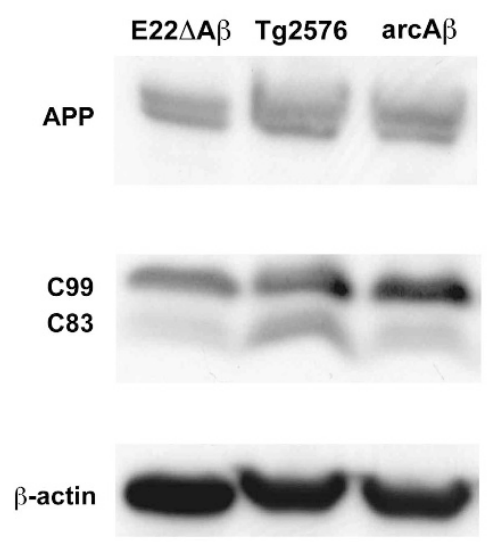

b

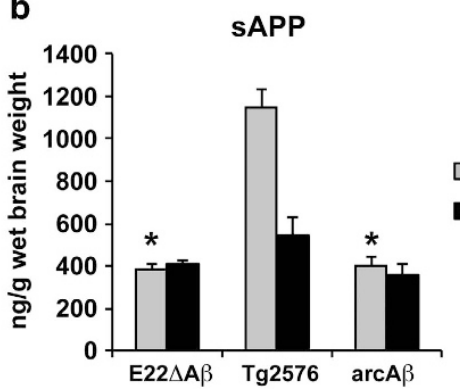

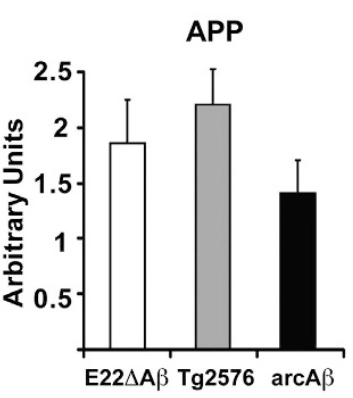
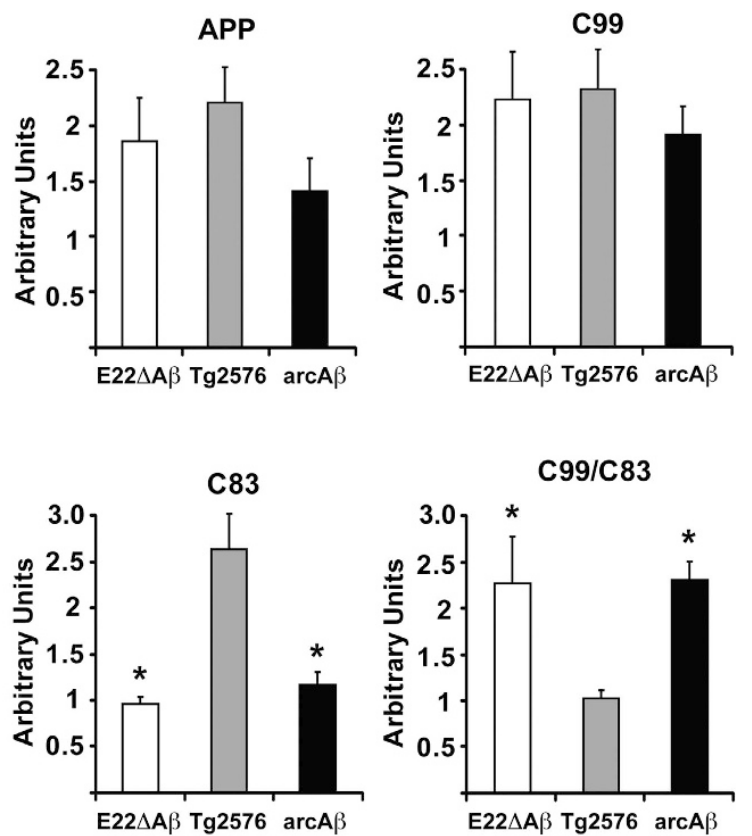

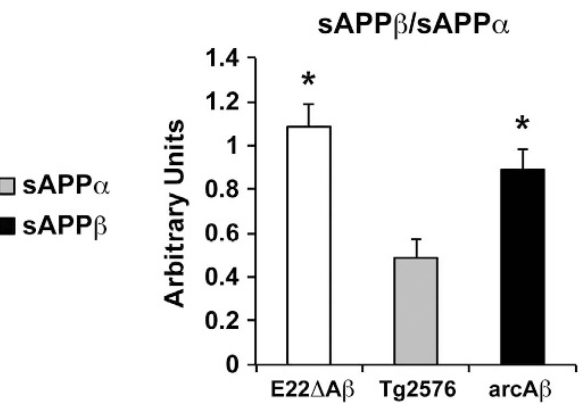

Figure 1 Intra-amyloid $\beta(A \beta)$ mutations decrease $\alpha$-cleavage in vivo. Transgene expression and A $\beta$ peptide precursor (APP) processing were compared in three mouse models of Alzhemier's disease (AD). (a) Western blot analysis of cortical SDS extracts from 3-month-old E22 $\triangle A \beta$ mice in comparison with age-matched Tg2576 and arcA $\beta$ mice. Full-length APP and APP C-terminal fragments (C99 and C83) were detected with a C-terminal-specific APP antibody and values normalized to $\beta$-actin. Quantification reveals significant reductions in $\alpha$-stub (C83) levels in both transgenic mouse lines bearing the intra-A $\beta$ mutation. This results in an increased C99/C83 ratio in the E22 $\triangle A \beta$ and $\operatorname{arcA} \beta$ mice as compared with the Tg2576 mice. ${ }^{*} P<0.05$ E22 $\triangle A \beta$ and $\operatorname{arcA} \beta$ vs Tg2576 (Mann-Whitney U-test). $n=4$ per group. (b) MSD analysis of sAPP $\alpha$ and SAPP $\beta$ levels in cortical samples extracted with Tris buffer containing $2 \%$ SDS. In accordance with the results of the APP CTF analysis, sAPP $\beta$ levels were not significantly different among the three APP transgenic mouse lines, whereas SAPP $\alpha$ was reduced almost threefold in the E22 $\triangle A \beta$ and arcA $\beta$ mice as compared with the Tg2576 mice. ${ }^{*} P=0.001 \mathrm{E} 22 \Delta \mathrm{A} \beta$ and $\operatorname{arcA} \beta$ vs Tg2576 (Mann-Whitney U-test). $n=6-8$ per group.

evidence of extracellular parenchymal amyloid deposition up to an age of 15 months (Figure $3 a$ and b). At 24 months of age, however, extracellular vascular amyloid deposits were observed in cortical and-more pronouncedcerebellar leptomeningeal vessels (Figure $4 a$ and b). Vascular amyloid deposits were thioflavin S (Figure 4c) and Congo red positive (Figure $4 \mathrm{~d}$ ), and were immunostained with several $A \beta$-specific antibodies (Figure $4 a-f$ ). Immunostainings with $A \beta 40$ - and $A \beta 42$-specific monoclonal antibodies revealed that $A \beta 40$ was the dominant $A \beta$ species deposited in the vessel walls of the E22 $\Delta A \beta$ mice (Figure $4 \mathrm{e}$ and f).

Early accumulation of intracellular $A \beta$ oligomers. Although extracellular (vascular) amyloid deposits were detectable in the E22 $\Delta \mathrm{A} \beta$ mice only as late as at the age of 24 months, immunostaining of paraffin-embedded brain sections with the monoclonal antibody $6 \mathrm{E} 10$ revealed prominent intraneuronal accumulation of dot-like aggregates mainly in hippocampal CA1 (Supplementary Figure 3a) and cortical (Supplementary Figure $3 b$ ) neurons that were observed already at the age of 3 months (data not shown). Double immunostaining with a polyclonal antibody directed against the APP $\mathrm{C}$ terminus (Supplementary Figure $3 \mathrm{c}$ and $\mathrm{d}$ ) showed little colocalization of $6 \mathrm{E} 10$ and APP immunoreactivity in the cortex and hippocampus (Supplementary Figure $3 e$ and $f$ ), thus excluding 6E10-positive aggregates as full-length APP or APP C-terminal fragments. Immunostaining with $A \beta$-specific antibodies directed against the $C$ terminus of $A \beta 40$ and $A \beta 42$ confirmed that the intraneuronal deposits indeed corresponded to $A \beta$ aggregates (Supplementary Figure 4a-f). Interestingly, immunostaining with the $A \beta 40$-specific antibody led to a more diffuse staining of both dot-like aggregates and neuronal cell bodies and 
a

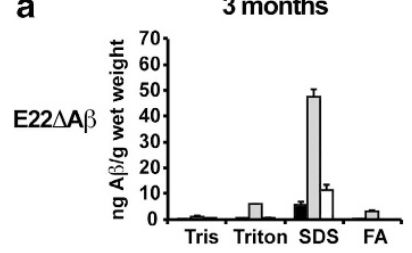

b

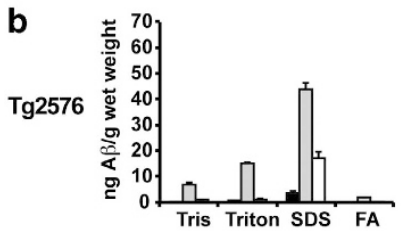

c

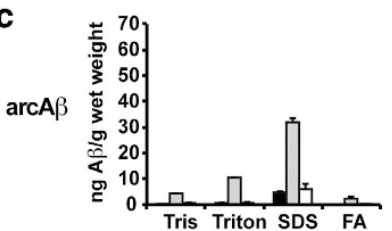

6 months

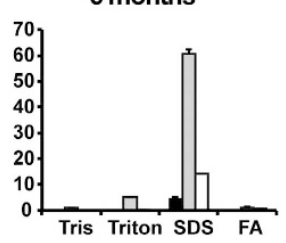

15 months

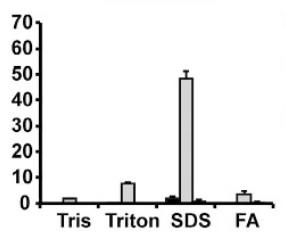

24 months

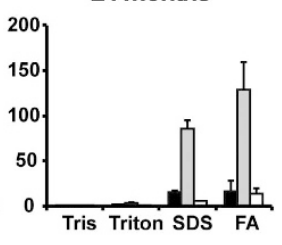

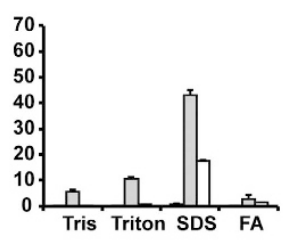
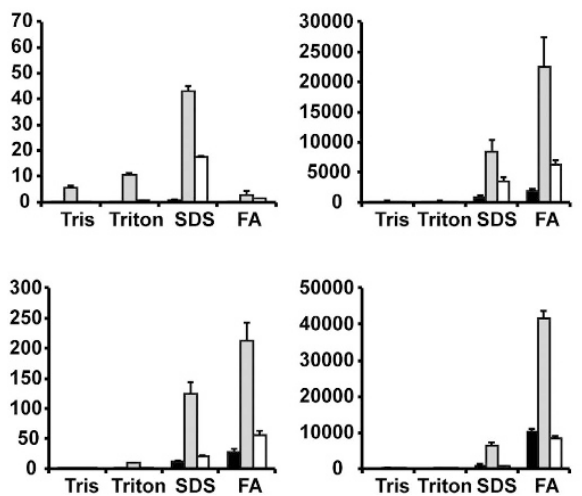

Figure 2 Accumulation of detergent-insoluble amyloid $\beta(A \beta)$ at different ages in the three Alzhemier's disease (AD) mouse models. MesoScale Discovery (MSD) analysis of $A \beta 38$ (black column), A 340 (gray column) and A $\beta 42$ (white column) in serially extracted cortical samples (Tris buffer, Tris buffer containing $1 \%$ Triton, Tris buffer containing $2 \%$ sodium dodecyl sulfate (SDS) and formic acid (FA)). (a) In E22 $\triangle A \beta$ mice most of the $A \beta$ can be detected in the SDS-soluble protein fraction up to the age of 15 months, whereas Tris buffer-soluble, Triton-soluble and FA-soluble A $\beta$ levels are comparatively low. Only at 24 months of age is detergent-insoluble $A \beta$ detected. (b) In contrast, Tg2576 mice show higher soluble $A \beta$ levels in Tris and Triton fractions and a prominent age-dependent $A \beta$ accumulation in the detergent-insoluble FA fraction at 15 months. (c) The 3-month-old arcA $\beta$ mice show intermediate Tris- and Triton-soluble $A \beta$ levels (as compared with age-matched E22 $\triangle A \beta$ and Tg2576 mice) and accumulation of $A \beta$ in the FA fraction already at the age of 6 months. $n=6-9$ per group.
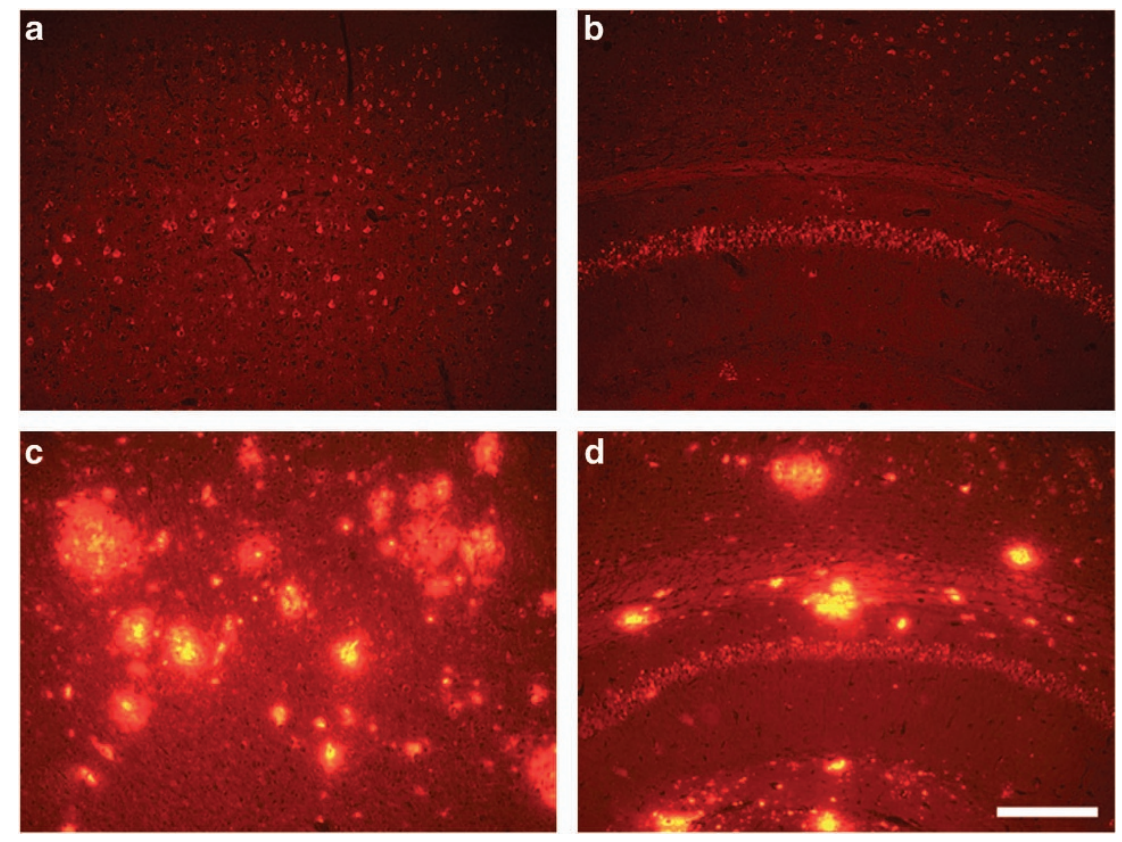

Figure 3 Lack of amyloid deposition in 15-month-old E22 $\triangle A \beta$ mice. (a-d) Immunostaining with antibody 6 E10 reveals a complete absence of extracellular amyloid deposits in 15-month-old E22 $\triangle \mathrm{A} \beta$ mice (a: cortex; $\mathbf{b}$ : hippocampus). In contrast, $\operatorname{arcA} \beta$ mice show a massive extracellular amyloid deposition at that age (c: cortex; d: hippocampus). Scale bars: $250 \mu \mathrm{m}(\mathbf{a}-\mathbf{d})$. A $\beta$, amyloid $\beta$.

processes (Supplementary Figure $4 a, b$ and e), whereas the A 342 -specific specifically stained compact intraneuronal aggregates (Supplementary Figure 4c, d and f).
Further characterization of the intraneuronal $A \beta$ aggregates in the E22 $\triangle A \beta$ mice with several oligomer-specific (conformation-dependent) antibodies revealed that the dot-like $A \beta$ 

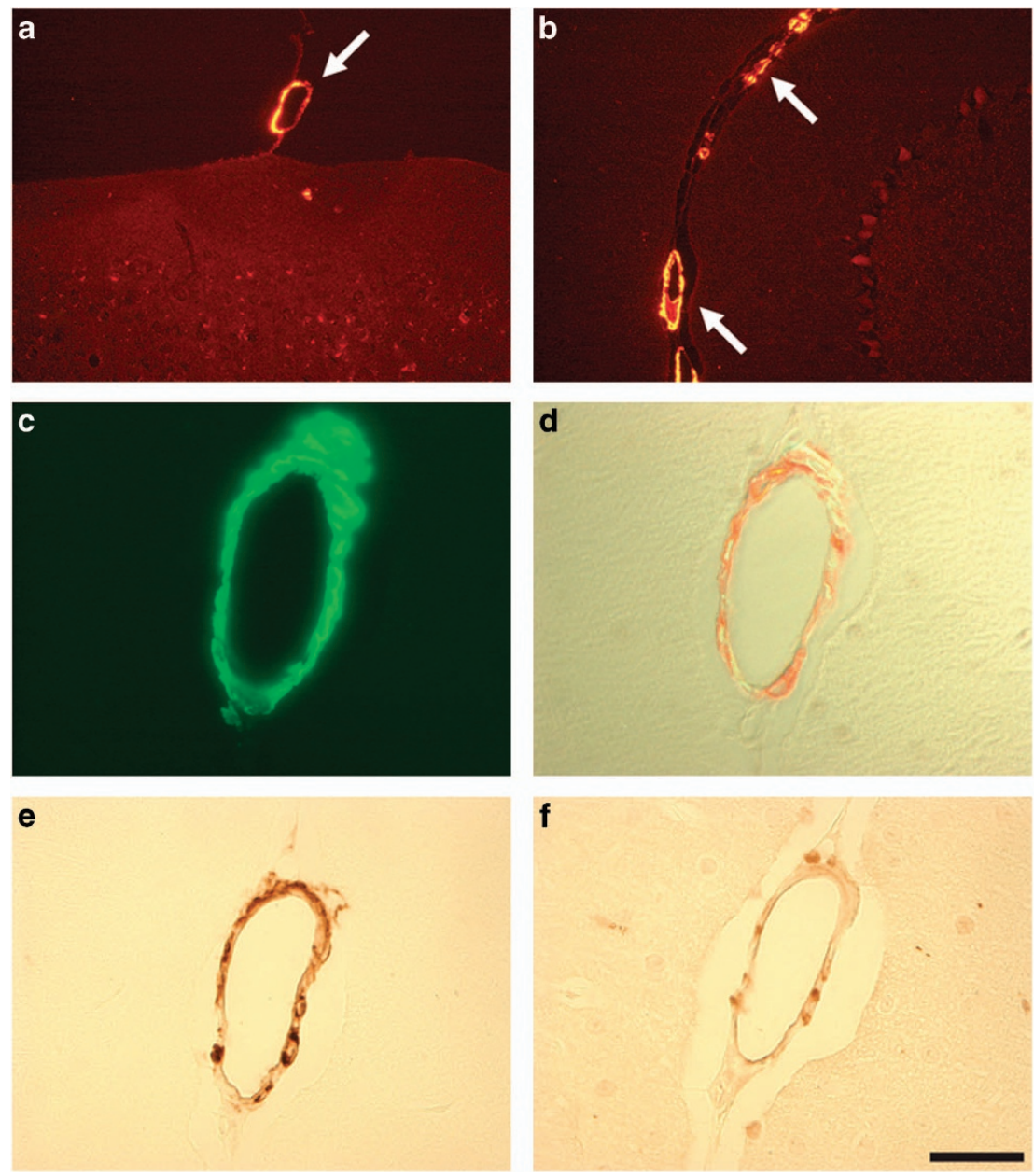

Figure 4 Aged E22 $\triangle \mathrm{A} \beta$ mice develop congophilic amyloid angiopathy $(\mathrm{CAA})$ at 24 months. $(\mathbf{a}+\mathbf{b})$ Immunostaining of amyloid-laden leptomeningeal vessels with polyclonal anti-amyloid antibody directed against human pan-A $\beta$ in the cortex (a) and cerebellum (b) of a 24-month-old E22 $\Delta A \beta$ mouse. (c $+\mathbf{d}$ ) Vascular amyloid deposits are thioflavin S (c) and Congo red positive (d). Note the classical apple-green birefringence of Congo red-stained vessels under polarized light (d). (e $+\mathbf{f})$ Immunostainings with A $\beta 40$-specific monoclonal antibody BA27 (e) and A 342 -specific monoclonal antibody BC05 (f) reveal that $A \beta 40$ is the dominant $A \beta$ species deposited in the vessel walls. Scale bars: $125 \mu \mathrm{m}(\mathbf{a}+\mathbf{b})$ and $40 \mu \mathrm{m}(\mathbf{c}-\mathbf{f})$. $A \beta$, amyloid $\beta$.

deposits were strongly stained by the polyclonal OC antibody directed against fibrillar $A \beta$ oligomers ${ }^{33}$ (Figure $\left.5 a-d\right)$, but not the A11 antibody directed against prefibrillar oligomers ${ }^{34}$ (Supplementary Figure $4 \mathrm{~g}$ and $\mathrm{h}$ ). OC-immunoreactive intraneuronal deposits were observed in CA1 hippocampal and cortical neurons as early as 3 months of age and appeared to grow and become more compact as the mice aged (Figure 5a-d). Strikingly, the intraneuronal oligomeric $A \beta$ deposits were also recognized by $11 \mathrm{~A} 1$ (Figure $5 \mathrm{e}$ and $\mathrm{f}$ ), a novel conformation-dependent monoclonal antibody specifically designed against the turn between positions 22 and 23 of the $A \beta$ sequence. $11 A 1$ has recently been shown to stain intraneuronal $A \beta$ aggregates in brains of $A D$ patients but not APP transgenic mice. ${ }^{26}$

Early cognitive deficits in transgenic E22 $\Delta \mathrm{A} \beta$ mice. Based on our previous findings in the $\operatorname{arc} A \beta$ mouse model in which intracellular $A \beta$ deposits occurred concomitantly with robust cognitive deficits, we hypothesized that the early accumulation of intraneuronal oligomeric $A \beta$ deposits, particularly in hippocampal brain regions of the $E 22 \Delta \mathrm{A} \beta$ mice, would also be accompanied by significant impairments on several cognitive tasks. Both $\mathrm{E} 22 \Delta \mathrm{A} \beta$ mice and wild-type littermates displayed, across all age groups, similar general health measures, auditory-visual sensory integrity, comparable grip strength, intact righting and extension reflexes. Assessment of body weight demonstrated equivalent body weights across all experimental groups, for both males and females. Locomotor and anxiety examination using the open field test demonstrated the published phenotype of increased locomotor activity and exploratory behavior, including increased total distance traveled, less time immobile and more time spent in the center zone, in transgenic mice (data not shown). Cognitive assessment in the Y-maze demonstrated a significant decrease in the percentage spatial alternation rate for $E 22 \Delta \mathrm{A} \beta$ mice at 3 months of age $\left(t_{(55)}=-3.16, P<0.005\right), 6$ months of age $\left(t_{(28)}=-1.727\right.$, $P<0.05)$ and 9 months of age $\left(t_{(16)}=-1.772, P<0.05\right)$, as compared with their wild-type littermates (Figure 6a). The Barnes maze was also used at 3 months of age as a second 

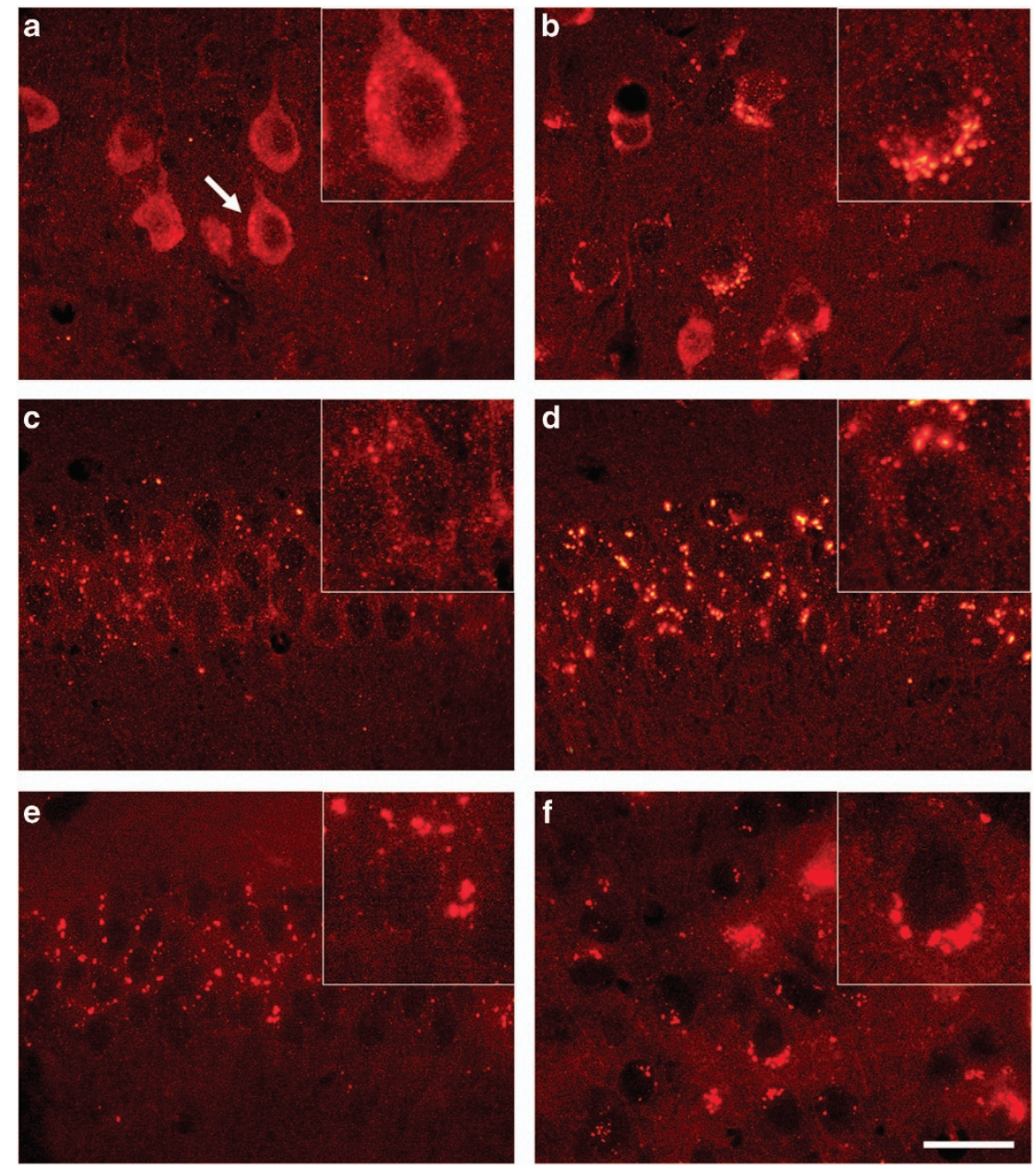

Figure 5 Intraneuronal amyloid $\beta(A \beta)$ consists of fibrillar oligomers bearing a 'toxic turn' conformation. (a-d) Immunostaining with polyclonal OC antibody directed against fibrillar A $\beta$ oligomers reveals age-dependent accumulation of intracellular oligomeric deposits in cortical (a and $\mathbf{b}$ ) and CA1 hippocampal neurons (c and $\mathbf{d})$. Note the temporal change of intraneuronal oligomers from rather diffuse and smaller dot-like aggregates at 3 months of age $(\mathbf{a}$ and $\mathbf{c})$ to bigger and more compact deposits at 15 months of age (b and d). (e and f) Conformation-dependent monoclonal antibody 11A1 directed against the turn between positions 22 and 23 of the $A \beta$ sequence stains hippocampal (e) and cortical (f) intraneuronal aggregates (representative immunostaining in a 15-month-old E22 $\Delta \mathrm{A} \beta$ mouse). Scale bar: $40 \mu \mathrm{m}$ (a-f).

hippocampus-dependent cognitive task to assess spatial learning and memory. Results demonstrated that both wildtype and transgenic E22 $\Delta \mathrm{A} \beta$ mice showed successful learning, with significantly lower latencies to escape over the 4 days of training (all $P^{\prime} s<0.05$; Figure 6b). Between genotypes, a significant main effect was shown for $E 22 \Delta \mathrm{A} \beta$ mice $\left(F_{(1,340)}=16.656, P<0.001\right)$. Fischer's least significant difference post hoc analysis demonstrated a significantly longer latency to escape for $\mathrm{E} 22 \Delta \mathrm{A} \beta$ mice, as compared with wildtype littermates on day $3(P=0.01)$ and day $4(P=0.03)$, with similar but nonsignificant trends on day $1(P=0.096)$ and day $2(P=0.095)$ (Figure 6b). Qualitative assessment of Barnes maze search strategies revealed a decrease in spatial search strategies in 3-month-old E22 $\Delta \mathrm{A} \beta$ mice (Figure $6 \mathrm{~d}$ ), as compared with wild-type control mice (Figure $6 c$ ).

Unique aggregation properties of recombinant E22 $\Delta$ mutated $\mathbf{A} \boldsymbol{\beta}$ peptides. In agreement with our previous findings that both $E 22 \Delta A \beta 40$ and $E 22 \Delta A \beta 42$ readily formed amyloid fibrils in vitro, we observed fibrillar (congophilic) amyloid deposits in vivo in aged APP transgenic E22 $\Delta \mathrm{A} \beta$ mice. Extracellular amyloid deposition in the E22 $\Delta \mathrm{A} \beta$ mice, however, only occurred as leptomeningeal CAA at an advanced age of 24 months (Figure 4), whereas wild-type A $\beta$-producing Tg2576 mice and E22G (Arctic) A $\beta$-producing $\operatorname{arc} A \beta$ mice accumulated fibrillar amyloid deposits at a much earlier age (Figures 2 and 3). ${ }^{27,31}$ To further investigate the biophysical basis of the E22 $\Delta$ intra-A $\beta$ mutation leading to early intracellular and very late extracellular amyloid deposition in vivo, we conducted in vitro thioflavin $\mathrm{T}$ aggregation assays of recombinant E22 $\Delta A \beta 40$ and $E 22 \Delta A \beta 42$ peptides. $\mathrm{E} 22 \Delta \mathrm{A} \beta$ aggregation curves were compared with the aggregation curves of $A \beta 40$ and $A \beta 42$ with wild-type or Arctic sequence (Figure 7). Measurements were terminated as the thioflavin $\mathrm{T}$ signal reached a plateau, after which the different $A \beta$ preparations were further incubated for a total of $1 \mathrm{~h}$, followed by western blot analysis. Results demonstrated typical aggregation kinetics of wild-type A $\beta 42$ and E22G A 342 peptides involving a lag phase, an exponential growth phase and a plateau phase of saturated fibril growth 

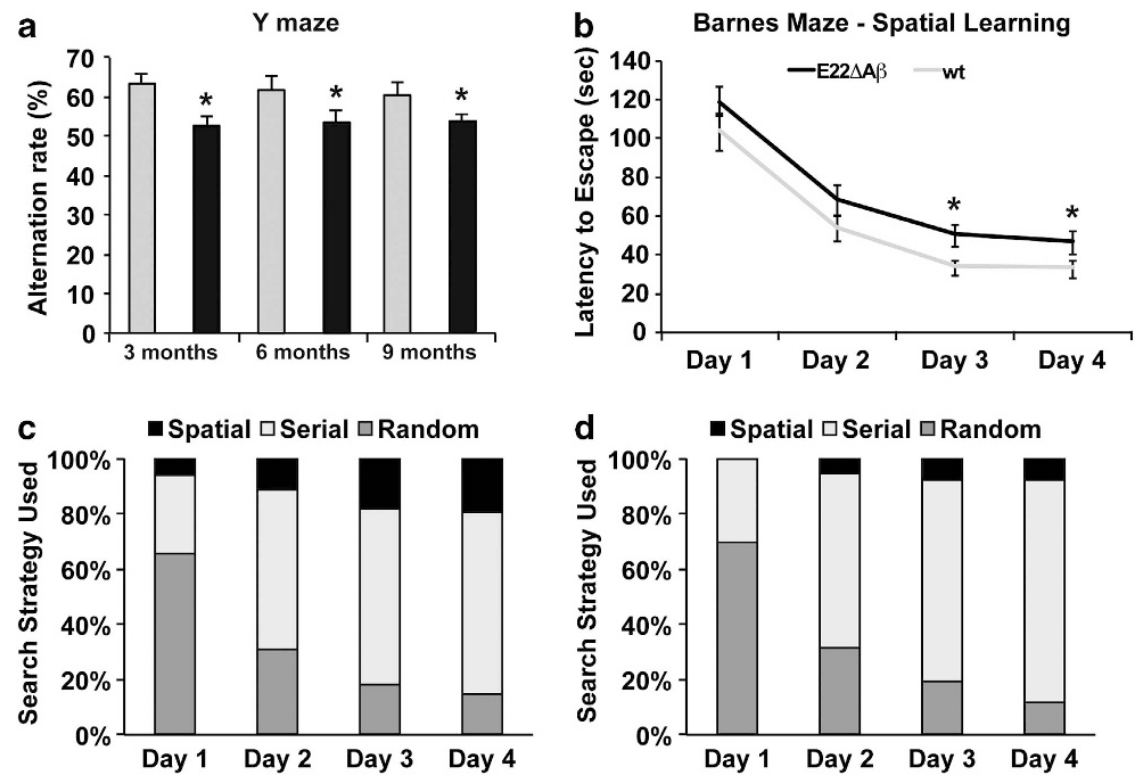

Figure 6 Early cognitive deficits in E22 $\triangle \mathrm{A} \beta$ mice. (a) Cognitive assessment in the $\mathrm{Y}$-maze demonstrates a significant decrease in the percentage spatial alternation rate for E22 $\triangle \mathrm{A} \beta$ mice as compared with their wild-type (wt) littermates at 3, 6 and 9 months of age ( $P<0.05$ for all comparisons; Student's $t$-test). (b) Assessment of Barnes maze spatial learning at the age of 3 months reveals that both wild-type and E22 $\Delta A \beta$ transgenic mice show successful learning over the 4 days of training. However, E22 $\Delta A \beta$ mice, as compared with wild-type littermates, show significantly higher latencies to escape on day $3(P=0.01)$ and day $4(P=0.03)$, with similar but nonsignificant trends on day 1 $(P=0.096)$ and day $2(P=0.095)$ (analysis of variance (ANOVA), followed by post hoc Fisher's least significant difference (LSD) analysis). (c and d) Qualitative assessment of Barnes maze search strategies reveals a decrease in spatial and relative increase in serial search strategies in 3-month-old E22 $\Delta A \beta$ mice (d) in comparison to wild-type control mice (c). $n=22-24$ per group. $A \beta$, amyloid $\beta$.

(Figure 7a and b). In contrast, no obvious lag phase and no exponential growth phase were observed for E22 $\Delta$ A $\beta 42$ at $2.5 \mu \mathrm{m}$ (Figure 7a) and-more obvious-at $5 \mu \mathrm{m}$ initial concentration (Figure 7b). Instead, E22 $\Delta$ A 342 showed a constant non-exponential increase in thioflavin $T$ fluorescence from time point 0 on and-in contrast to E22G and wild-type A 342 -formed detergent-insoluble high-molecularweight aggregates immediately after reconstitution at $\mathrm{pH} 7.4$, as revealed by western blotting of the recombinant peptide preparations that were used for the thioflavin $T$ analysis (Figure 7c). Thioflavin $T$ analysis of recombinant $A \beta 40$ peptide variants revealed a dramatically accelerated fibril formation for both E22 $\Delta$ and E22G $A \beta 40$ in comparison to wild-type $A \beta 40$ (Figure $7 d$ ). In contrast to E22 $\Delta A \beta 42$, E22 $\Delta$ A 340 aggregation was characterized by a lag phase, an exponential growth phase and a plateau phase with unusually high absolute thioflavin $T$ fluorescence values indicating increased thioflavin T binding capacity of the E22 $\Delta$ A 340 peptide as reported previously. ${ }^{24}$

In summary, thioflavin $T$ analysis of recombinant E22 $\Delta$ $A \beta 42$ and E22 $\triangle A \beta 40$ aggregation kinetics confirmed our previous findings of a highly increased fibrillogenic property of single preparations of the two peptide variants. ${ }^{24}$

Inhibition of E22 $\Delta A \beta$ aggregation in the presence of wild-type $\mathbf{A} \boldsymbol{\beta}$. The E693 $\triangle$ APP mutation is one of the two currently known familial AD mutations in the $A P P$ gene with a recessive Mendelian trait of inheritance. ${ }^{9,35}$ The second recessive mutation, $\mathrm{A} 673 \mathrm{~V}$, has recently been shown to be highly amyloidogenic in the homozygous state, but antiamyloidogenic in the heterozygous state as revealed by an inhibition of $A \beta$ aggregation when mutated and wild-type peptides were co-incubated. ${ }^{35}$ We hypothesized similar effects on the aggregation kinetics when incubating mixtures of the wild-type and E22 $\Delta$-mutated $A \beta$ peptides. Coaggregation of wild-type $A \beta 42$ with $E 22 \Delta A \beta 42$ led to a significant extension of the lag phase and a delay of the growth phase in comparison to the aggregation of wild-type $A \beta 42$ alone. This effect was specific for the E22 $\Delta$ intra-A $\beta$ mutation, as it was not observed with the E22G $A \beta 42$ variant. In contrast, co-aggregation of E22G (Arctic) A $\beta 42$ with wildtype $A \beta 42$ revealed a similar aggregation kinetics as E22G A $\beta 42$ alone (see Figure 8a). Similarly, the aggregation of E22 $\triangle A \beta 40$ peptides was also significantly delayed in mixtures containing $50 \%$ wild-type $A \beta 40$, whereas coincubation of E22G $A \beta 40$ with wild-type $A \beta 40$ only slightly delayed fibril formation in comparison to E22G $A \beta 40$ alone (Figure $8 b$ ). In conclusion, only the $E 22 \Delta$ intra-A $\beta$ mutation (but not the E22G variant) was associated with a significant delay of aggregation in the heterozygous state, simulated by equal mixtures with wild-type $A \beta$ peptides.

Inhibition of E22 $\Delta$ A 340 aggregation in the presence of E22 $\triangle$ A 342 . Based on our results that co-incubation of wildtype $A \beta$ with $E 22 \Delta A \beta$ significantly delayed amyloid fibril formation, we hypothesized that co-incubation of E22 $\Delta$ $A \beta 40$ with E22 $A \beta 42$ may have similar antifibrillogenic effects. Therefore, recombinant E22 $\Delta A \beta 40$ and E22 $\Delta A \beta 42$ peptides were co-incubated in a physiological 9:1 ratio at $2.5 \mu \mathrm{M}$, and the increase in thioflavin $\mathrm{T}$ fluorescence was monitored over time (Figure $8 \mathrm{c}$ ). We found a dramatic delay of the growth phase and a remarkable loss of absolute 

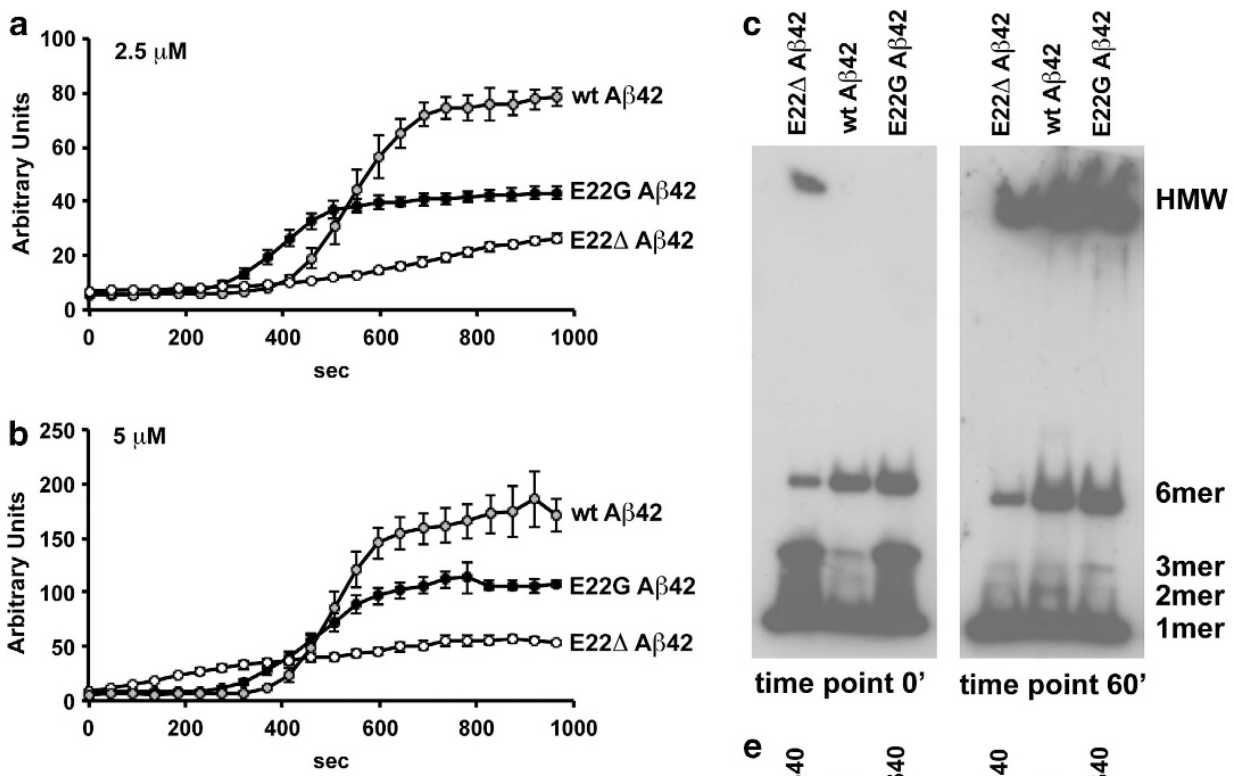

d

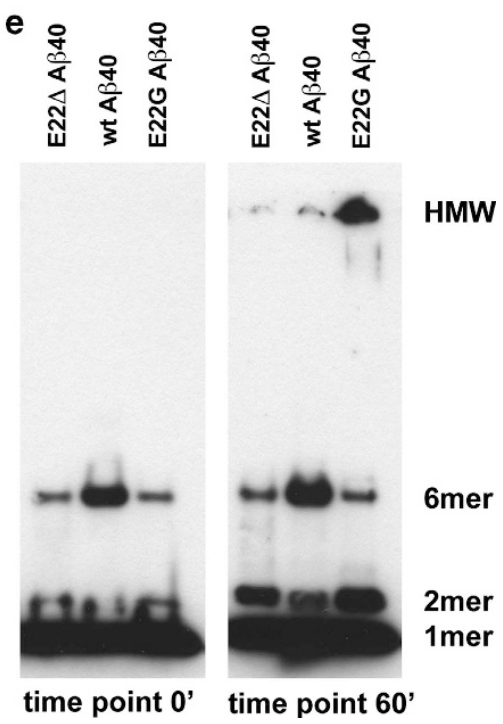

Figure 7 Unique aggregation kinetics of recombinant E22 $\Delta \mathrm{A} \beta$ peptides in vitro. Fibril formation is measured via the absolute increase in thioflavin $\mathrm{T}$ fluorescence at $482 \mathrm{~nm}$ during aggregation. Aggregation of amyloid $\beta(A \beta)$ peptides (identical total monomer concentrations: $2.5 \mu \mathrm{m}$ in $\mathbf{a}+\mathbf{c}, 5 \mu \mathrm{m}$ in $\mathbf{b}$ ) at pH 7.4 and $37^{\circ} \mathrm{C}$ is initiated by a 10 fold dilution of $A \beta$ stock solutions in $10 \mathrm{~mm} \mathrm{NaOH}$ with buffer. Average curves of three independent experiments are shown ( \pm s.e.m.). (a and $\mathbf{b})$ Thioflavin T analysis of E22G (Arctic) $A \beta 42$ and wild-type (wt) A $\beta 42$ reveals that a typical aggregation kinetics with a lag phase, which is shorter for E22G $A \beta 42$ than wild-type $A \beta 42$, is followed by an exponential growth phase that eventually reaches a plateau of saturated $\beta$-sheet formation. In contrast, no obvious lag phase and no exponential growth phase is observed for E22 $\Delta$ A 342 at $2.5 \mu \mathrm{m}$ (a) and-more obvious-at $5 \mu \mathrm{m}$ (b). Instead, E22 $\Delta$ A 342 is characterized by slow non-exponential fibril growth; however, it forms detergent-insoluble high molecular weight (HMW) aggregates immediately after reconstitution at $\mathrm{pH} 7.4$ as revealed by western blotting of the recombinant peptide preparations that were used for the thioflavin T analysis at time point 0 and time point 60 of the assay (c). (d) In contrast to E22 $\triangle A \beta 42, E 22 \Delta A \beta 40$-similar to E22G A 340 -shows an aggregation kinetics characterized by a lag phase, an exponential growth phase and a plateau phase. Note the unusually high thioflavin T fluorescence values for $E 22 \triangle A \beta 40$ in contrast to $E 22 G$ and wild-type $A \beta 40$, and the remarkably shorter lag phases of the E22-mutated $A \beta 40$ variants in comparison to the wild-type peptide. (e) In contrast to the amyloid $\beta$ (A $\beta 42$ ) analysis, western blot analysis of the $A \beta 40$ peptide variants reveals no immediate formation of detergent-insoluble HMW aggregates at time point 0 min. Only the E22G mutant develops prominent HMW aggregates after $60 \mathrm{~min}$.

thioflavin $T$ fluorescence when we compared the aggregation curve with the aggregation curve of E22 $\triangle A \beta 40$ alone (Figures $7 d$ and $8 c$ ). Again in contrast, 9:1 mixtures of E22G $A \beta 40$ and $E 22 G A \beta 42$ resulted in rapid aggregation, similar to E22G AB40 alone (Figures $7 \mathrm{c}$ and $8 \mathrm{c}$ ). These results again reveal the strong aggregating properties of the E22G mutation and the inhibitory effect of the E22 $\Delta$ mutation under conditions when different peptide species coexist, as is the case in vivo.
Poor seeding of wild-type A 342 aggregation by E22A A 342 fibrils. Based on the assumption that amyloid formation can be seeded by preformed amyloid fibrils, we finally addressed the question whether preaggregated E22 $\triangle A \beta 42$ fibrils were capable of (a) seeding their own growth and (b) seeding the growth of wild-type $A \beta 42$ fibrils. As control experiments, wild-type $A \beta 42$ and E22G (Arctic) A $A 42$ fibrils were incubated with preparations of their respective monomeric peptides, which resulted in an immediate increase in 

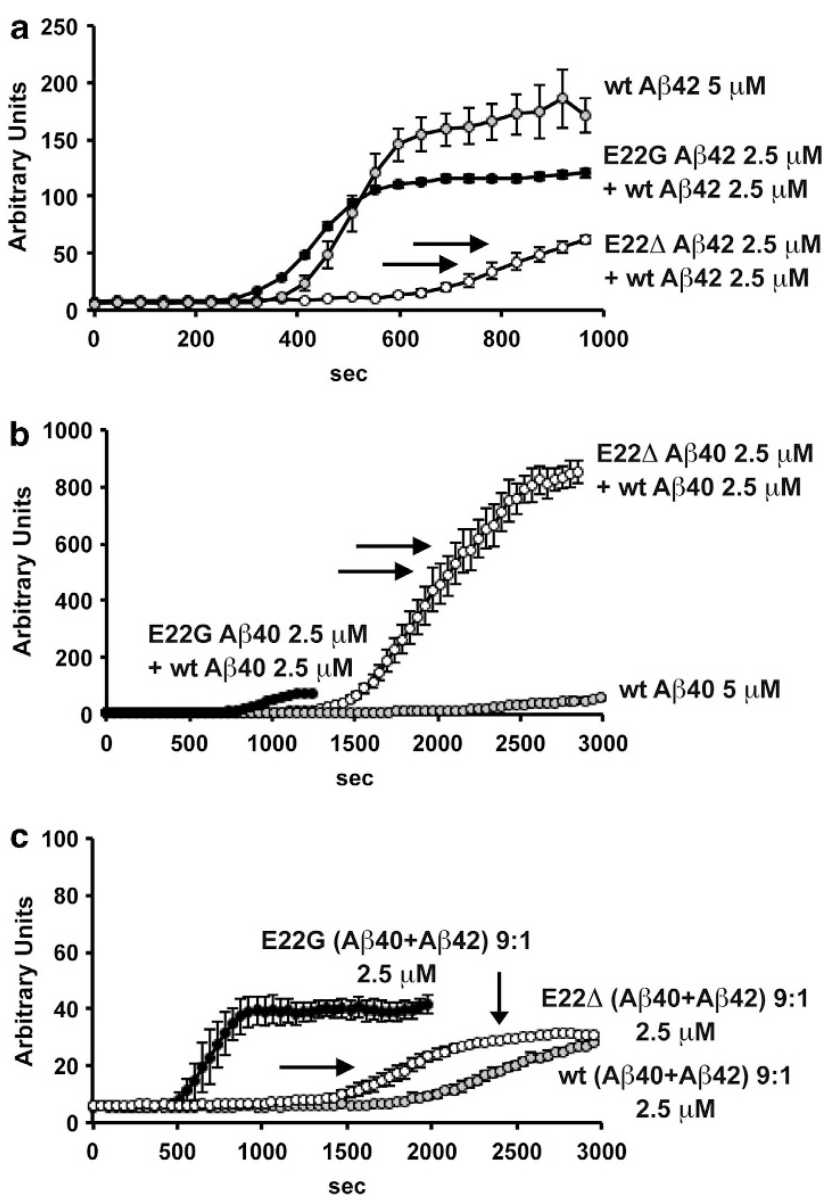

Figure 8 Anti-amyloidogenic property of E22 $\triangle A \beta$ peptides in mixtures of different $A \beta$ peptide variants. (a and $\mathbf{b})$ Co-aggregation of E22 $\triangle A \beta 42$ with wildtype (wt) $A \beta 42$ (a) or E22 $\triangle A \beta 40$ with wild-type $A \beta 40$ (b) leads to a significant extension of the lag phase and a delay of the growth phase in comparison with the aggregation of the respective $A \beta$ peptide variants alone (see Figure 7) (total monomer concentrations for each peptide variant: $2.5 \mu \mathrm{M}$ ). In contrast, coaggregation of $2.5 \mu \mathrm{m} E 22 \mathrm{G}$ (Arctic) $\mathrm{A} \beta 42$ with $2.5 \mu \mathrm{m}$ wild-type $\mathrm{A} \beta 42$ (a) results in a similar aggregation curve as with 2.5 or $5 \mu \mathrm{m}$ E22G A $\beta 42$ alone (see Figure 7). Coaggregation of E22G $A \beta 40$ with wild-type $A \beta 40$ (b) only slightly delays $\beta$-sheet formation in comparison with E22G A $\beta 40$ alone. (c) Co-aggregation of E22 $\triangle A \beta 40$ with E22 $\triangle A \beta 42$ in a physiological 9:1 ratio (total monomer end concentration in solution: $2.5 \mu \mathrm{m}$ ) leads to a strong inhibition of E22 $\triangle \mathrm{A} \beta 40$ aggregation. Note the dramatic delay of the growth phase and remarkable loss of absolute thioflavin $T$ fluorescence in comparison to E22 $\triangle A \beta 40$ alone (Figure 7). In contrast, 9:1 mixtures of E22G $A \beta 40$ and E22G A $\beta 42$ result in an aggregation curve very similar to $E 22 G$ AB40 alone. Average curves of three independent experiments are shown ( \pm s.e.m.).

thioflavin T fluorescence without a lag phase, thus indicating good seeding properties (Supplementary Figure $4 a$ and b). Incubation of preaggregated E22 $\Delta$ A $\beta 42$ fibrils with fresh preparations of E22 $\Delta A \beta 42$ peptide also resulted in an immediate increase in thioflavin $T$ fluorescence that was steeper as compared with the aggregation curve of E22 $\Delta$ A $\beta 42$ in the absence of fibrillar seeds (Figure $7 a$ and Supplementary Figure $5 c$ ). However, when E22 $\Delta$ A $\beta 42$ fibrils were used for the seeding of wild-type $A \beta 42$, a significant delay of fibril formation was observed, which indicated poor seeding properties (Supplementary Figure 5e). In contrast,
E22G A 342 fibrils appeared only slightly inferior to wildtype $A \beta 42$ fibrils in seeding wild-type $A \beta 42$ aggregation (Supplementary Figure 5d).

\section{Discussion}

Homozygous E693 $\triangle$ APP mutation carriers develop an ADlike clinical phenotype characterized by early memory disturbances, visuospatial deficits and executive dysfunction, followed by atypical neurological signs including cerebellar ataxia and gait difficulties during later stages of the disease. $^{9,36}$ Brain amyloid imaging by Pittsburgh Compound $\mathrm{B}$ positron emission tomography revealed a very weak signal in E693 $\triangle$ APP mutation carriers with advanced dementia, suggesting that $A D$-like clinical symptoms occurred in the absence of relevant amyloid deposition in these patients. . $^{9,36}$ In vitro experiments with synthetic E22 $\Delta \mathrm{A} \beta 40$ and $E 22 \Delta \mathrm{A} \beta 42$ peptide preparations demonstrated an enhanced oligomerization propensity, but no fibril formation, ${ }^{9}$ and led to the hypothesis that AD-like dementia in patients can be caused by the sole presence of synaptotoxic $A \beta$ oligomers, which was well in line with previous experimental findings. ${ }^{37-43}$ In contrast to these initial in vitro findings, subsequent work, including our own recent study with highly pure recombinant peptide preparations, demonstrated that both E22 $\triangle A \beta 40$ and E22 $\triangle A \beta 42$ readily formed amyloid fibrils in vitro. ${ }^{20,24,44}$ Based on these in vitro findings, we hypothesized that E22 $\triangle A \beta 40$ and E22 $\triangle A \beta 42$ would, at least in principle, also form amyloid fibrils in vivo. Indeed, aged $E 22 \Delta A \beta$ mice accumulated detergent-insoluble $A \beta$ and showed thioflavin $S$ and Congo red-positive amyloid deposits in leptomeningeal cortical and-more pronounced-cerebellar vessels; in contrast to the recently published E693 $\Delta$ mouse model, which completely lacked extracellular amyloid deposition even at an age of 24 months, ${ }^{22}$ E22 $\Delta \mathrm{A} \beta$ mice overexpress human APP at levels comparable to those in the Tg2576 mouse line, and the introduction of the Swedish double mutation results in an additional increase in total $A \beta$ levels. ${ }^{6}$ Taken together, this might explain the differences between our model and the $\mathrm{E} 693 \Delta$ mice. Interestingly, CAA deposits in the E22 $\Delta A \beta$ mice were more pronounced in the leptomeningeal vasculature of the cerebellum than in cortical vessels, which is in agreement with recent amyloid positron emission tomography findings in E693 $\Delta$ mutation carriers showing a relative increase in Pittsburgh Compound $\mathrm{B}$ retention in cerebellar brain regions. ${ }^{36}$ The identification of CAA as a key neuropathological feature of aged E22 $\Delta A \beta$ mice adds the Osaka $E 693 \Delta$ mutation to the list of vasculotropic intra-A $\beta$ APP mutations essentially comprising all of the currently known mutations at or around position 22 of the $A \beta$ sequence (for a review see Kumar-Singh ${ }^{18}$ ). Our immunohistological analysis of CAA deposits identified $A \beta 40$ as the major E22 $\Delta A \beta$ species depositing in the vessel walls of the E22 $\Delta A \beta$ mice, which is in line with previous findings in sporadic and familial $A D$ cases, ${ }^{45,46}$ including the Dutch E693Q APP mutation. ${ }^{47}$ Further experiments are needed to elucidate the mechanisms underlying the vasculotropism of E22 $\Delta$-mutated $A \beta$ and whether similar mechanisms as previously reported for the Dutch mutation (that is, a reduced receptor-mediated clearance across the blood-brain barrier) have a role. ${ }^{48,49}$ 
$\mathrm{E} 22 \Delta \mathrm{A} \beta$ mice-similar to our previously reported $\operatorname{arcA} \beta$ mice $^{27}$ - develop intraneuronal $A \beta$ aggregates that coincide with cognitive deficits beginning at 3 months of age. Intraneuronal $A \beta$ accumulation is generally believed to be an early event in AD pathogenesis, although its relevance and role in the disease process remain a controversial topic. ${ }^{50-52}$ This may be partly due to technical considerations, including the use of nonspecific antibodies for the detection of intraneuronal $A \beta$. The intraneuronal $A \beta$ staining in our $\mathrm{E} 22 \Delta \mathrm{A} \beta$ mouse model only partially colocalized with staining of the APP $C$ terminus, excluding false interpretation of $A \beta$ staining emerging from full-length APP or APP C-terminal fragments. Furthermore, intraneuronal $A \beta$ was stained by different $A \beta$ C-terminus-specific antibodies, which do not crossreact with APP or APP fragments, including BC05 and $\mathrm{BA} 27 .^{53}$ These results therefore indicate that the intraneuronal aggregates in the $E 22 \Delta A \beta$ mice indeed correspond to $A \beta$ and not accumulating APP/APP fragments. The assembly state of the intraneuronal aggregates was characterized by immunohistochemistry using several oligomer-specific antibodies. Accumulation of intracellular oligomeric $A \beta$ species has recently been reported in other APP transgenic mouse lines, including the McGill-Thy1-APP mice, ${ }^{54}$ the $3 \times \mathrm{Tg}^{-} \mathrm{AD}^{55}$ and the E693 $\Delta$ mice. ${ }^{22}$ Further immunohistological characterization of the intraneuronal deposits in the $E 22 \Delta \mathrm{A} \beta$ mice revealed that the intraneuronal aggregates were strongly stained by $\mathrm{OC}$ antibody, directed against fibrillar oligomers, but not A11 antibody, which recognizes prefibrillar oligomers. ${ }^{33,34}$ Interestingly, soluble fibrillar oligomers detected by OC antibody (but not prefibrillar oligomers) have recently been shown to be elevated in multiple brain regions of AD patients and to correlate with cognitive dysfunction. ${ }^{56}$ Building on the hypothesis that intra- $A \beta$ mutations at or around position 22 of the $A \beta$ increase $A \beta$ fibrillogenesis through a facilitation of $a$ 'toxic turn' conformation between positions 22 and 23 of the $\mathrm{A} \beta$ sequence, ${ }^{57}$ Murakami et al. $^{26}$ developed a novel monoclonal antibody (11A1) directed against this specific conformational epitope of $A \beta 42$. In human $A D$ brains, $11 A 1$ stained both extracellular and intracellular $A \beta$ deposits, whereas in APP transgenic Tg2576 mice, only extracellular deposits were labeled. ${ }^{26}$ Interestingly, $11 \mathrm{~A} 1$ stained intraneuronal $A \beta$ aggregates in the brains of the $E 22 \Delta A \beta$ mice, suggesting that the oligomeric E22 $\Delta$-mutated $A \beta$ deposits contained the 'toxic turn' conformation.

Western blot and MSD analysis of APP cleavage products from cortical brain extracts revealed a relative increase in amyloidogenic ( $\beta$-secretase-mediated) APP processing in the two mouse models bearing the E22 intra-A $\beta$ APP mutations, which is in accordance with previous in vitro findings. ${ }^{21,58,59}$ As both E22 $\triangle \mathrm{A} \beta$ and $\operatorname{arcA} \beta$ mice overexpress similar fulllength APP, sAPP $\beta$ and $C 99$ levels, but significantly reduced sAPP $\alpha$ and C83 levels, as compared with the Tg2576 mice, we concluded that the two intra-A $\beta$ mutations specifically interfered with the $\alpha$-secretase cleavage of APP in vivo. Previous in vitro reports in the Arctic mutation revealed that E693G APP was not a poor substrate to $\alpha$-secretase, but instead reduced APP levels at the cell surface making Arctic APP less available for $\alpha$-secretase cleavage, and increasing A $\beta$ levels, especially at intracellular locations. ${ }^{58}$ Similar to the Arctic APP mutation, E693 $\Delta$ APP overexpression in cell culture was also associated with reduced extracellular $A \beta$ levels in vitro. ${ }^{21,58,59}$ Although these results may imply similar effects of the two intra-A $\beta$ mutations on APP processing, we currently cannot exclude E693 $\Delta$ APP as an inferior substrate to $\alpha$-secretase-mediated cleavage, thus leading to the relative increase in amyloidogenic APP processing, as shown previously for other intra-A $\beta$ APP mutations, including the Flemish E692G APP mutation. ${ }^{60}$

MSD analysis revealed a marked reduction of buffer- and Triton buffer-soluble brain $A \beta$, as well as peripheral plasma $A \beta$ levels, in particular when $\mathrm{E} 22 \Delta \mathrm{A} \beta$ mice were compared with age-matched Tg2576 mice-expressing wild-type A $\beta$. This indicated that the absence of extracellular amyloid deposition up to an age of 15 months was not associated with a relative increase in soluble brain or plasma $A \beta$ levels. Instead, most of the $A \beta$ accumulated in the SDS-soluble protein fraction likely corresponding to intraneuronal $A \beta$ pools. These results are in agreement with recent in vitro results from cell culture experiments showing increased intracellular $A \beta$ accumulation, but markedly reduced secreted $A \beta$ levels in E693 $\triangle$ APPtransfected cell lines. ${ }^{9,21,23}$ The early accumulation of intracellular fibrillar oligomeric $A \beta$ deposits in brains of the $\mathrm{E} 22 \Delta \mathrm{A} \beta$ mice is in line with the unique aggregation profiles of the recombinant E22 $\Delta A \beta 40$ and E22 $\Delta A \beta 42$ peptides showing accelerated $\beta$-sheet formation in thioflavin T aggregation assays as compared with the respective wild-type $A \beta$ peptides $^{20,24,44}$ (and this study). When aggregation curves of $E 22 \Delta$, E22G and wild-type $A \beta 40$ and $A \beta 42$ were compared, $E 22 \Delta A \beta 42$ showed the highest fibrillogenesis propensity as it aggregated without a lag phase and formed SDS-resistant amyloid fibrils immediately after reconstitution in solution at $\mathrm{pH}$ 7.4. However, E22 $\Delta \mathrm{A} \beta 42$ fibril growth after reconstitution in solution occurred only in a slow, non-exponential manner in contrast to the other peptides, including E22 $\Delta A \beta 40$, whose aggregation was characterized by an exponential growth phase following lag phase. This slow fibril growth and lack of exponential growth in E22 $\Delta A \beta 42$ may be a crucial factor in the prevention of extracellular amyloid deposition in the $E 22 \Delta A \beta$ mice.

Apart from A673V, a recently described familial AD APP mutation in an Italian pedigree, E693 $\Delta$, is the second currently known recessive APP mutation that is pathogenic only in the homozygous state. ${ }^{9,35}$ Similar to the A673V mutation, which is antiamyloidogenic in the heterozygous state, ${ }^{35}$ our coaggregation experiments with recombinant E22 $\Delta \mathrm{A} \beta$ peptide variants also revealed an inhibition of $A \beta$ aggregation when mutated and wild-type peptides were co-incubated. In contrast, co-aggregation of E22G (Arctic) A $\beta$ peptides with the respective wild-type $A \beta$ peptides resulted in aggregation curves very similar to those of the E22G A $\beta$ peptides alone. Moreover, E22 $\triangle A \beta 42$ fibrils, in contrast to wild-type $A \beta 42$ and E22G A 342 fibrils, only very inefficiently seeded wild-type A 342 fibrillogenesis. These results provide a possible explanation why heterozygous carriers of the E693 $\Delta$ mutation do not develop the disease, whereas heterozygous carriers of the autosomal dominant Arctic mutation develop dementia.

Hence, we propose the following hypothetical model to explain the phenotype of the Osaka E693 $\Delta$ mutation, in which $\mathrm{E} 22 \Delta \mathrm{A} \beta$ aggregation occurs primarily in intracellular compartments where peptide concentrations are high enough to allow 
for aggregate formation (Supplementary Figure 6). Outside the cell, E22 $\triangle \mathrm{A} \beta$ peptide variants may interact with each other-and possibly also other peptides -in a way that results in an inhibition of aggregation and amyloid seed formation. Moreover, the E22 $\Delta$ A $\beta 42$ peptide shows specific aggregation properties (slow non-exponential growth, lack of exponential growth phase) that likely further prevent parenchymal amyloid plaque deposition (Supplementary Figure 6). However, late vascular amyloid deposition occurs possibly due to the vasculotropism of the E22-mutated $A \beta$ peptide variant and age-related changes along perivascular clearing pathways (Supplementary Figure 6).

\section{Conflict of interest}

Noriaki Kinoshita is employee of Immuno-Biological Laboratories, Gunma, Japan. Luka Kulic, Jordan McAfoose, Tobias Welt, Christian Tackenberg, Claudia Späni, Fabian Wirth, Verena Finder, Uwe Konietzko, Maria Giese, Anne Eckert, Takahiro Shimizu, Kazuma Murakami, Kazuhiro Irie, Suhail Rasool, Charles Glabe, Christoph Hock and Roger M Nitsch have no competing interests to declare.

Acknowledgements. We thank Anna Jeske for technical support. This study was supported in part by the Swiss National Science Foundation Grant No. 33CM30-124111/1 and the Forschungskredit grant of the University of Zurich.

1. Thal DR, Del Tredici K, Braak H. Neurodegeneration in normal brain aging and disease. $\mathrm{Sci}$ Aging Knowledge Environ 2004; 2004: pe26.

2. Thal DR, Griffin WS, Braak H. Parenchymal and vascular Abeta-deposition and its effects on the degeneration of neurons and cognition in Alzheimer's disease. J Cell Mol Med 2008; 12: $1848-1862$

3. Hardy J, Selkoe DJ. The amyloid hypothesis of Alzheimer's disease: progress and problems on the road to therapeutics. Science 2002; 297: 353-356.

4. Tanzi RE, Bertram L. Twenty years of the Alzheimer's disease amyloid hypothesis: a genetic perspective. Cell 2005; 120: 545-555.

5. Citron M, Oltersdorf T, Haass C, McConlogue L, Hung AY, Seubert P et al. Mutation of the beta-amyloid precursor protein in familial Alzheimer's disease increases beta-protein production. Nature 1992; 360: 672-674.

6. Haass C, Lemere CA, Capell A, Citron M, Seubert P, Schenk D et al. The Swedish mutation causes early-onset Alzheimer's disease by beta-secretase cleavage within the secretory pathway. Nat Med 1995; 1: 1291-1296.

7. Mullan M, Crawford F, Axelman K, Houlden H, Lilius L, Winblad B et al. A pathogenic mutation for probable Alzheimer's disease in the APP gene at the N-terminus of betaamyloid. Nat Genet 1992; 1: 345-347.

8. Goate AM. Monogenetic determinants of Alzheimer's disease: APP mutations. Cell Mol Life Sci 1998; 54: 897-901.

9. Tomiyama T, Nagata T, Shimada H, Teraoka R, Fukushima A, Kanemitsu $\mathrm{H}$ et al. A new amyloid beta variant favoring oligomerization in Alzheimer's-type dementia. Ann Neurol 2008; 63: 377-387.

10. Levy E, Carman MD, Fernandez-Madrid IJ, Power MD, Lieberburg I, van Duinen SG et al. Mutation of the Alzheimer's disease amyloid gene in hereditary cerebral hemorrhage, Dutch type. Science 1990; 248: 1124-1126.

11. Hendriks $L$, van Duijn $C M$, Cras $P$, Cruts $M$, Van Hul W, van Harskamp F et al. Presenile dementia and cerebral haemorrhage linked to a mutation at codon 692 of the beta-amyloid precursor protein gene. Nat Genet 1992; 1: 218-221.

12. Bugiani O, Giaccone G, Rossi G, Mangieri M, Capobianco R, Morbin M et al. Hereditary cerebral hemorrhage with amyloidosis associated with the E693K mutation of APP. Arch Neurol 2010; 67: 987-995.

13. Grabowski TJ, Cho HS, Vonsattel JP, Rebeck GW, Greenberg SM. Novel amyloid precursor protein mutation in an lowa family with dementia and severe cerebral amyloid angiopathy. Ann Neurol 2001; 49: 697-705.

14. Nilsberth C, Westlind-Danielsson A, Eckman CB, Condron MM, Axelman K, Forsell C et al. The 'Arctic' APP mutation (E693G) causes Alzheimer's disease by enhanced Abeta protofibril formation. Nat Neurosci 2001; 4: 887-893.

15. Haass C, Hung AY, Selkoe DJ, Teplow DB. Mutations associated with a locus for familial Alzheimer's disease result in alternative processing of amyloid beta-protein precursor. J Biol Chem 1994; 269: 17741-17748.
16. Fraser PE, Nguyen JT, Inouye H, Surewicz WK, Selkoe DJ, Podlisny MB et al. Fibril formation by primate, rodent, and Dutch-hemorrhagic analogues of Alzheimer amyloid beta-protein. Biochemistry 1992; 31: 10716-10723.

17. Murakami K, Irie K, Morimoto A, Ohigashi $\mathrm{H}$, Shindo M, Nagao M et al. Neurotoxicity and physicochemical properties of Abeta mutant peptides from cerebral amyloid angiopathy: implication for the pathogenesis of cerebral amyloid angiopathy and Alzheimer's disease. J Biol Chem 2003; 278: 46179-46187.

18. Kumar-Singh S. Hereditary and sporadic forms of abeta-cerebrovascular amyloidosis and relevant transgenic mouse models. Int J Mol Sci 2009; 10: 1872-1895.

19. Takuma H, Teraoka R, Mori H, Tomiyama T. Amyloid-beta E22Delta variant induces synaptic alteration in mouse hippocampal slices. NeuroReport 2008; 19: 615-619.

20. Suzuki T, Murakami K, Izuo N, Kume T, Akaike A, Nagata T et al. E22Delta mutation in amyloid beta-protein promotes beta-sheet transformation, radical production, and synaptotoxicity, but not neurotoxicity. Int J Alzheimer's Dis 2011; 2011: 431320

21. Nishitsuji K, Tomiyama T, Ishibashi K, Ito K, Teraoka R, Lambert MP et al. The E693Delta mutation in amyloid precursor protein increases intracellular accumulation of amyloid beta oligomers and causes endoplasmic reticulum stress-induced apoptosis in cultured cells. Am J Pathol 2009; 174: 957-969.

22. Tomiyama T, Matsuyama S, Iso H, Umeda T, Takuma H, Ohnishi K et al. A mouse model of amyloid beta oligomers: their contribution to synaptic alteration, abnormal tau phosphorylation, glial activation, and neuronal loss in vivo. J Neurosci 2010; 30: 4845-4856.

23. Umeda T, Tomiyama T, Sakama N, Tanaka S, Lambert MP, Klein WL et al. Intraneuronal amyloid beta oligomers cause cell death via endoplasmic reticulum stress, endosomal/ lysosomal leakage, and mitochondrial dysfunction in vivo. J Neurosci Res 2011; 89: 1031-1042.

24. Ovchinnikova OY, Finder VH, Vodopivec I, Nitsch RM, Glockshuber R. The Osaka FAD mutation E22Delta leads to the formation of a previously unknown type of amyloid beta fibrils and modulates Abeta neurotoxicity. J Mol Biol 2011; 408: 780-791.

25. Borchelt DR, Davis J, Fischer M, Lee MK, Slunt HH, Ratovitsky T et al. A vector for expressing foreign genes in the brains and hearts of transgenic mice. Genet Anal 1996; 13: $159-163$

26. Murakami K, Horikoshi-Sakuraba Y, Murata N, Noda Y, Masuda Y, Kinoshita N et al. Monoclonal antibody against the turn of the 42-residue amyloid $\beta$-protein at positions 22 and 23. ACS Chem Neurosci 2010; 1: 747-756.

27. Knobloch M, Konietzko U, Krebs DC, Nitsch RM. Intracellular Abeta and cognitive deficits precede beta-amyloid deposition in transgenic arcAbeta mice. Neurobiol Aging 2007; 28: 1297-1306.

28. Finder VH, Vodopivec I, Nitsch RM, Glockshuber R. The recombinant amyloid-beta peptide Abeta1-42 aggregates faster and is more neurotoxic than synthetic Abeta1-42. J Mol Biol 2010; 396: 9-18.

29. Crawley JN. Mouse behavioral assays relevant to the symptoms of autism. Brain Pathol 2007; 17: 448-459.

30. Paul CM, Magda G, Abel S. Spatial memory: theoretical basis and comparative review on experimental methods in rodents. Behav Brain Res 2009; 203: 151-164.

31. Hsiao K, Chapman P, Nilsen S, Eckman C, Harigaya Y, Younkin S et al. Correlative memory deficits, Abeta elevation, and amyloid plaques in transgenic mice. Science 1996; 274: 99-102.

32. Kawarabayashi T, Younkin LH, Saido TC, Shoji M, Ashe KH, Younkin SG. Age-dependent changes in brain, CSF, and plasma amyloid (beta) protein in the Tg2576 transgenic mouse model of Alzheimer's disease. J Neurosci 2001; 21: 372-381.

33. Kayed R, Head E, Sarsoza F, Saing T, Cotman CW, Necula M et al. Fibril specific, conformation dependent antibodies recognize a generic epitope common to amyloid fibrils and fibrillar oligomers that is absent in prefibrillar oligomers. Mol Neurodegener 2007; 2: 18.

34. Kayed R, Head E, Thompson JL, McIntire TM, Milton SC, Cotman CW et al. Common structure of soluble amyloid oligomers implies common mechanism of pathogenesis. Science 2003; 300: 486-489

35. Di Fede G, Catania M, Morbin M, Rossi G, Suardi S, Mazzoleni G et al. A recessive mutation in the APP gene with dominant-negative effect on amyloidogenesis. Science 2009; 323: 1473-1477.

36. Shimada H, Ataka S, Tomiyama T, Takechi H, Mori H, Miki T. Clinical course of patients with familial early-onset Alzheimer's disease potentially lacking senile plaques bearing the E693Delta mutation in amyloid precursor protein. Dement Geriatr Cogn Disord 2011; 32: 45-54

37. Cleary JP, Walsh DM, Hofmeister JJ, Shankar GM, Kuskowski MA, Selkoe DJ et al. Natural oligomers of the amyloid-beta protein specifically disrupt cognitive function. Nat Neurosci 2005; 8: 79-84.

38. Lacor PN, Buniel MC, Furlow PW, Clemente AS, Velasco PT, Wood M et al. Abeta oligomerinduced aberrations in synapse composition, shape, and density provide a molecular basis for loss of connectivity in Alzheimer's disease. J Neurosci 2007; 27: 796-807.

39. Lambert MP, Barlow AK, Chromy BA, Edwards C, Freed R, Liosatos M et al. Diffusible, nonfibrillar ligands derived from Abeta1-42 are potent central nervous system neurotoxins. Proc Natl Acad Sci USA 1998; 95: 6448-6453.

40. Lesne S, Koh MT, Kotilinek L, Kayed R, Glabe CG, Yang A et al. A specific amyloid-beta protein assembly in the brain impairs memory. Nature 2006; 440: 352-357. 
41. Shankar GM, Bloodgood BL, Townsend M, Walsh DM, Selkoe DJ, Sabatini BL. Natural oligomers of the Alzheimer amyloid-beta protein induce reversible synapse loss by modulating an NMDA-type glutamate receptor-dependent signaling pathway. J Neurosci 2007; 27: 2866-2875

42. Townsend M, Shankar GM, Mehta T, Walsh DM, Selkoe DJ. Effects of secreted oligomers of amyloid beta-protein on hippocampal synaptic plasticity: a potent role for trimers. J Physiol 2006; 572(Part 2): 477-492.

43. Walsh DM, Klyubin I, Fadeeva JV, Cullen WK, Anwyl R, Wolfe MS et al. Naturally secreted oligomers of amyloid beta protein potently inhibit hippocampal long-term potentiation in vivo. Nature 2002; 416: 535-539.

44. Inayathullah M, Teplow DB. Structural dynamics of the DeltaE22 (Osaka) familial Alzheimer's disease-linked amyloid beta-protein. Amyloid 2011; 18: 98-107.

45. Kumar-Singh S. Cerebral amyloid angiopathy: pathogenetic mechanisms and link to dense amyloid plaques. Genes Brain Behav 2008; 7((Suppl 1)): 67-82.

46. Kumar-Singh S, Cras P, Wang R, Kros JM, van Swieten J, Lubke U et al. Dense-core senile plaques in the Flemish variant of Alzheimer's disease are vasocentric. Am J Pathol 2002; 161: 507-520.

47. Herzig MC, Winkler DT, Burgermeister P, Pfeifer M, Kohler E, Schmidt SD et al. Abeta is targeted to the vasculature in a mouse model of hereditary cerebral hemorrhage with amyloidosis. Nat Neurosci 2004; 7: 954-960.

48. Deane R, Wu Z, Sagare A, Davis J, Du Yan S, Hamm K et al. LRP/amyloid beta-peptide interaction mediates differential brain efflux of Abeta isoforms. Neuron 2004; 43: 333-344.

49. Monro OR, Mackic JB, Yamada S, Segal MB, Ghiso J, Maurer $C$ et al. Substitution at codon 22 reduces clearance of Alzheimer's amyloid-beta peptide from the cerebrospinal fluid and prevents its transport from the central nervous system into blood. Neurobiol Aging 2002; 23: $405-412$.

50. LaFerla FM, Green KN, Oddo S. Intracellular amyloid-beta in Alzheimer's disease. Nat Rev Neurosci 2007; 8: 499-509.

51. Gouras GK, Tampellini D, Takahashi RH, Capetillo-Zarate E. Intraneuronal beta-amyloid accumulation and synapse pathology in Alzheimer's disease. Acta Neuropathol 2010; 119: 523-541.

52. Tampellini D, Gouras GK. Synapses, synaptic activity and intraneuronal abeta in Alzheimer's disease. Front Aging Neurosci 20102.

53. Winton MJ, Lee EB, Sun E, Wong MM, Leight S, Zhang B et al. Intraneuronal APP, not free Abeta peptides in $3 \times \mathrm{Tg}$-AD mice: implications for tau versus Abeta-mediated Alzheimer neurodegeneration. J Neurosci 2011; 31: 7691-7699.

54. Ferretti MT, Bruno MA, Ducatenzeiler A, Klein WL, Cuello AC. Intracellular Abetaoligomers and early inflammation in a model of Alzheimer's disease. Neurobiol Aging 2012; 33: $1329-1342$

55. Oddo S, Caccamo A, Tran L, Lambert MP, Glabe CG, Klein WL et al. Temporal profile of amyloid-beta (Abeta) oligomerization in an in vivo model of Alzheimer disease. A link between Abeta and tau pathology. J Biol Chem 2006; 281: 1599-1604.

56. Tomic JL, Pensalfini A, Head E, Glabe CG. Soluble fibrillar oligomer levels are elevated in Alzheimer's disease brain and correlate with cognitive dysfunction. Neurobiol Dis 2009; 35 352-358.

57. Murakami K, Masuda Y, Shirasawa T, Shimizu T, Irie K. The turn formation at positions 22 and 23 in the 42-mer amyloid beta peptide: the emerging role in the pathogenesis of Alzheimer's disease. Geriatr Gerontol Int 2010; 10((Suppl 1)): S169-S179.

58. Sahlin C, Lord A, Magnusson K, Englund H, Almeida CG, Greengard P et al. The Arctic Alzheimer mutation favors intracellular amyloid-beta production by making amyloid precursor protein less available to alpha-secretase. J Neurochem 2007; 101: 854-862.

59. Stenh C, Nilsberth C, Hammarback J, Engvall B, Naslund J, Lannfelt L. The Arctic mutation interferes with processing of the amyloid precursor protein. NeuroReport 2002; 13: 1857-1860.

60. Lammich S, Kojro E, Postina R, Gilbert S, Pfeiffer R, Jasionowski M et al. Constitutive and regulated alpha-secretase cleavage of Alzheimer's amyloid precursor protein by a disintegrin metalloprotease. Proc Natl Acad Sci USA 1999; 96: 3922-3927.

(c)

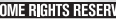
published by Nature Publishing Group. This work is licensed under the Creative Commons Attribution-NonCommercial-No Derivative Works 3.0 Unported License. To view a copy of this license, visit http://creativecommons.org/licenses/by-nc-nd/3.0/

Supplementary Information accompanies the paper on the Translational Psychiatry website (http://www.nature.com/tp) 